\title{
Republic of Poland: Arrangement Under the Flexible Credit Line—Staff Report; Staff Supplement; Press Release on the Executive Board Discussion; and Statement by the Executive Director for the Republic of Poland
}

In the context of the arrangement for the Republic of Poland under the Flexible Credit Line, the following documents have been released and are included in this package:

- $\quad$ The staff report on the Arrangement for the Republic of Poland Under the Flexible Credit Line, prepared by a staff team of the IMF, based on information available as of April 24, 2009. The views expressed in the staff report are those of the staff team and do not necessarily reflect the views of the Executive Board of the IMF.

- $\quad$ A staff supplement of April 28, 2009, on the assessment of the impact of the proposed Flexible Credit Line arrangement on the Fund's finances and liquidity position.

- $\quad$ A Press Release summarizing the views of the Executive Board as expressed during its May 6, 2009, discussion of the staff report that completed the review.

- $\quad$ A statement by the Executive Director for the Republic of Poland.

The policy of publication of staff reports and other documents allows for the deletion of market-sensitive information.

Copies of this report are available to the public from

International Monetary Fund • Publication Services

$70019^{\text {th }}$ Street, N.W. • Washington, D.C. 20431

Telephone: (202) 623-7430 • Telefax: (202) 623-7201

E-mail: publications@imf.org • Internet: http://www.imf.org

\section{International Monetary Fund Washington, D.C.}



INTERNATIONAL MONETARY FUND

REPUBLIC OF POLAND

Arrangement Under the Flexible Credit Line

Prepared by the European Department

(In consultation with other departments)

Approved by Marek Belka and Philip Gerson

April 24, 2009

Background. Poland has pursued very strong policies. Despite a booming economy and rapidly expanding credit, acute macroeconomic imbalances have been avoided in recent years. Most recently, the policy response to the negative spillovers from the global crisis has been timely and appropriate. Moreover, Poland's institutional policy framework has proven effective and helped underpin confidence in policies, as recognized by the Executive Board in the past.

Outlook. Notwithstanding Poland's favorable fundamentals and the authorities' strong policy response, the economy is being severely affected by the global financial crisis through both the real and financial sector channels. Exports and credit growth are slowing sharply, with an attendant fast deceleration in output growth. Risks to the banking sector have increased, but are expected to remain manageable. Importantly, international capital market access has been preserved during a difficult period.

$\boldsymbol{F C L}$. The authorities believe that access under an FCL arrangement in the amount of SDR 13.69 billion (1000 percent of quota), which they intend to treat as precautionary, could help maintain market access and safeguard against downside risks during the current period of high volatility and retrenchment in international capital markets. Staff concurs and believes that, given Poland's regional importance, the FCL may provide insurance not only to Poland, but to the region more broadly. In staff's view, Poland fully meets the criteria for access to an FCL.

Fund liquidity. The impact of the proposed commitment of SDR 13.69 billion on the Fund's finances and liquidity position would be manageable.

Process. An informal meeting to consult with the Executive Board on a possible FCL arrangement for Poland was held on April 13, 2009.

Team: The report was prepared by a staff team lead by Poul M. Thomsen and comprising Alexander Hoffmaister, Natan Epstein, and Mali Chivakul (all EUR), and Manuela Goretti (SPR). 


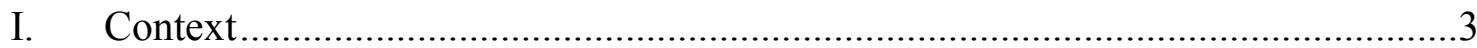

A. Very Strong Fundamentals ..................................................................... 3

B. Proven Policy Track Record ...................................................................4

C. Spillover from the Global Crisis ................................................................6

D. Strong Policy Response to the Recent Spillovers .........................................10

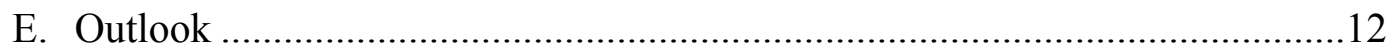

II. Role of the Flexible Credit Line and Access .................................................... 13

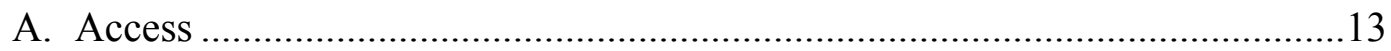

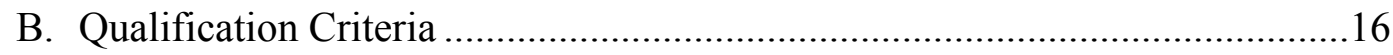

III. Impact on Fund Finances, Risks, and Safeguards.........................................21

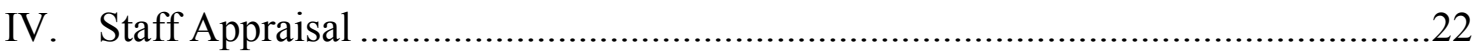

Boxes

1. Measures to Safeguard Financial Sector Stability ..........................................11

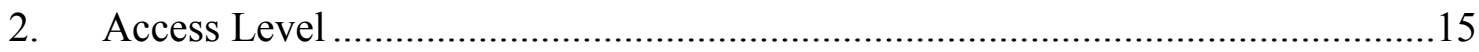

Figures

1. Recent Economic Developments, 2001-09 ......................................................

2. Recent Financial Markets Developments, April 2008-April 2009 .......................8

3. Balance of Payments Developments, 2000-08 .................................................

4. Reserve Coverage in International Perspective .................................................14

5. Qualification Criteria ................................................................................. 18

6. External Debt Sustainability: Bound Tests .....................................................19

7. Public Debt Sustainability: Bound Tests ......................................................20

Tables

1. Selected Economic Indicators, 2005-10 ........................................................23

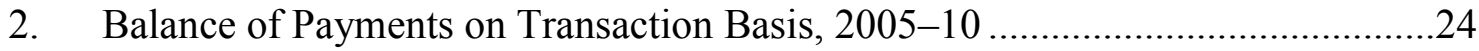

3. External Debt Sustainability Framework, 2003-13 ..........................................25

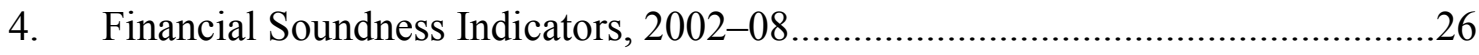

5. General Government Revenues and Expenditures, 2005-10 ..............................27

6. Public Sector Debt Sustainability Framework, 2003-13 …..............................28

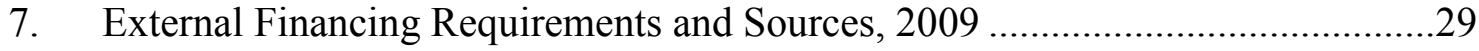

8. Assumptions Underlying Adverse Financing Scenario ....................................30

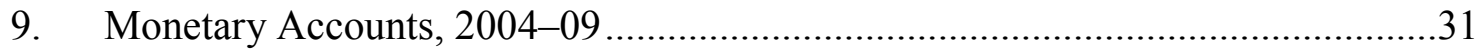

Attachment

Letters from Authorities 


\section{ConteXt}

\section{A. Very Strong Fundamentals}

1. Poland's macroeconomic performance has been very strong. Output growth in recent years - averaging about 6 percent in 2006-08 - has been well-balanced, as EU accession bolstered business confidence and spurred a long-awaited rise in investment (Table 1). Private consumption growth has also been robust, driven by rapidly rising real wages, increasing employment, and record-high credit growth. The output response reflected primarily a significant increase in labor utilization, although rising investment and productivity also played a role. Emerging capacity constraints, not least in the labor market, had caused some moderate weakening of output growth even before the global crisis began to spill over to Poland. Moreover, inflationary pressures started to increase in early 2007 but such pressures remained manageable.

\section{Despite a booming economy, the current account deficit has remained relatively} low and the external position sustainable. Even as export growth was robust and Poland continued to gain export market shares, buoyant imports resulted in some widening of the current account deficit. However, as a share of GDP, this deficit has remained relatively low and external debt has been stable at about 40-50 percent of GDP (Tables 2 and 3). ${ }^{1}$ Staff estimates suggest that the real exchange rate is broadly in equilibrium. ${ }^{2}$

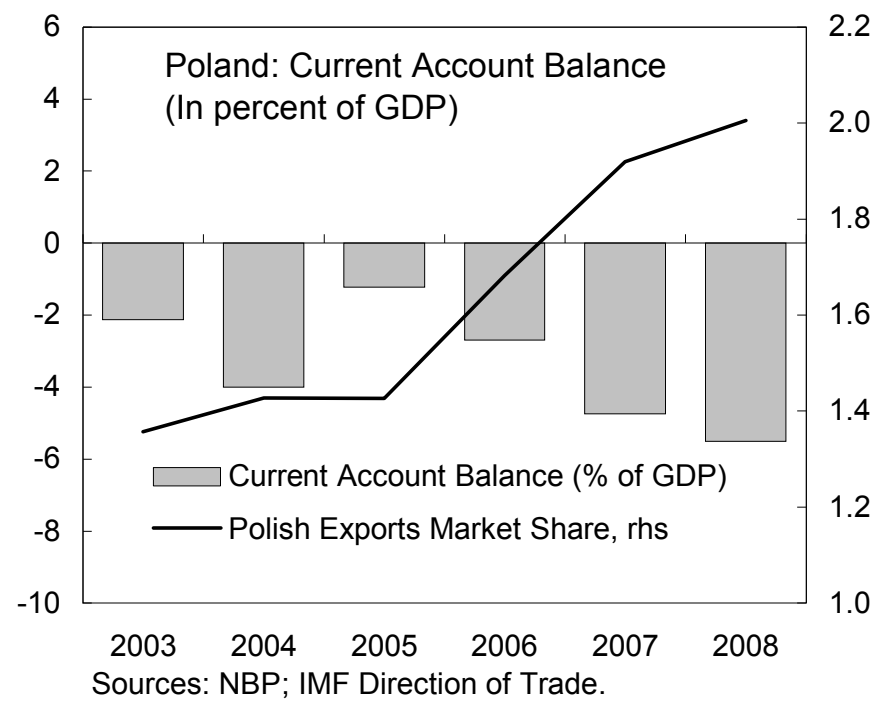

\footnotetext{
${ }^{1}$ The estimated underlying current account deficit is consistent with the debt-stabilizing level in the medium term.

${ }^{2}$ Preliminary CGER estimates (March, 2009) suggest that estimated deviations from the equilibrium real exchange rate are within the margin of error of the estimation.
} 


\section{Credit has been expanding rapidly, but the banking sector remains well}

capitalized. Household credit (primarily FX-denominated mortgages) exhibited fast growth, albeit from a small base. While corporate lending also expanded quickly, its growth was more moderate. To fund the credit expansion, foreign-owned banks (representing about 80 percent of the banking sector in terms of assets) increasingly borrowed from their parent banks. In the wake of the credit expansion, capital-adequacy ratios have declined, but the banking system remains well-capitalized, with a high ratio of tier 1 capital and record profits in 2008 (Table 4).

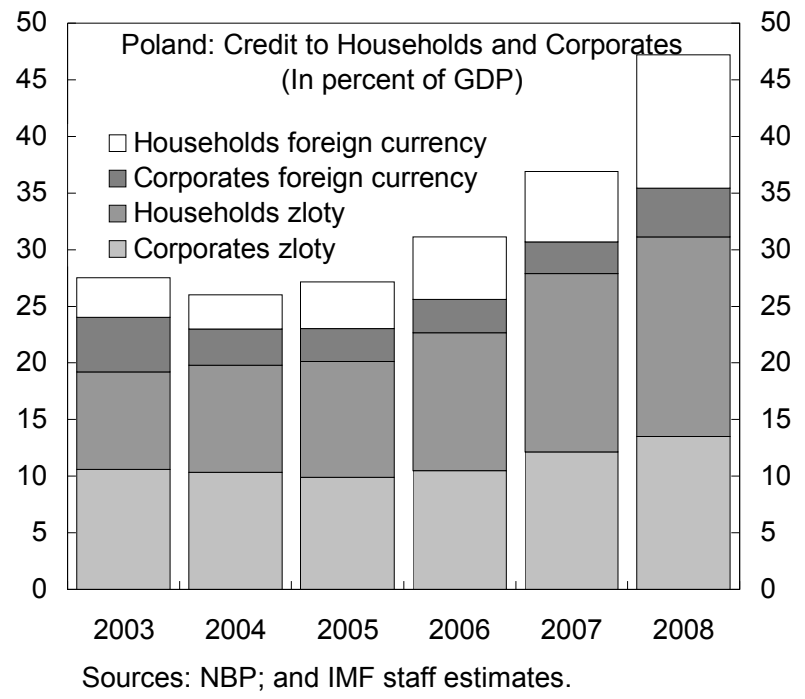

\section{B. Proven Policy Track Record}

\section{The avoidance of acute imbalances during the boom years owes much to very strong and timely policy response:}

- Monetary policy. A determined anti-inflationary focus - in the context of a longstanding and effective inflation targeting regime and a freely-floating exchange rate-had helped build confidence in monetary institutions and anchor inflation and inflation expectations early in the decade. This led to a prolonged period of low and stable inflation. A new tightening cycle began in April 2007 in response to a renewed increase in inflation. While inflation rose above the upper end of the $1 \frac{1}{2}$ to $3 \frac{1}{2}$ percent tolerance range, peaking at 4.8 percent, it had begun to stabilize before spillovers from the global crisis intensified. In addition, the flexible exchange rate regime has buffered external shocks and allowed the real exchange rate to adjust.

- Fiscal policy. The authorities' 2012 euro adoption target and their EU commitments have provided a strong fiscal anchor. The fiscal deficit was reduced to 2 percent of GDP in 2007-comfortably below the Maastricht ceiling of 3 percent of GDP — and Poland's Excessive Deficit Procedure was abrogated in 
July 2008. Still, the fiscal deficit exceeded 3 percent of GDP in 2008, primarily due to revenue shortfalls associated with a marked slowdown in the economy in late 2008. Spending cuts in fourth quarter of 2008 allowed the state budget to remain on target (with a small margin), but these cuts did not offset higher deficits at lower levels of government (Tables 5 and 6).

- Financial sector. Banking supervision has been strengthened to be fully compliant with EU laws and directives. As foreign currency-denominated mortgage lending gained pace, supervisors responded in a timely manner with measures that, in effect, placed constraints on FX-lending. Furthermore, the institutional framework for financial stability has been buttressed by the unification of financial supervision under the aegis of the Polish Financial Supervision Authority (KNF) on January 1, 2008 and the recent creation of the Financial Stability Committee. The committee-comprised of representatives from the Ministry of Finance, the National Bank of Poland and the KNFprovides a formal framework that has enhanced informational flows and analytical activities and has been actively engaged in furthering contingency planning.

- Structural reforms. In view of the emerging labor market bottlenecks, structural policies have focused on boosting the exceptionally low labor participation rate. The tax wedge has been lowered by cutting in half disability contributions and eligibility for early retirement has been significantly curtailed, slashing the number of eligible workers from above one million to about 250,000. The authorities have also given priority to deregulation and completing their privatization plan.

5. The Fund has strongly supported the authorities' policy stance. The most recent Article IV consultation was concluded in April 2008 (Country Report No. 08/130), with Executive Directors assessing policies very positively. Directors noted the strong and wellbalanced growth and credible institutions, and welcomed the commitment to macroeconomic stability, reinvigoration of structural reforms, and adoption of the euro. They recognized the limited upward pressures on core inflation, despite rising demand pressures, and noted that this reflected the credibility of the authorities' strong anti-inflation policy. They stressed the importance of strengthening the medium-term budgetary framework and welcomed the authorities' determination to speed up fiscal consolidation and reduce the medium-term deficit. Finally, Directors noted the soundness of the banking system and the limited exposure to the US subprime market. 


\section{Spillover from the Global Crisis}

6. Despite very strong fundamentals, Poland's economy is now being severely affected by the global crisis, albeit less so than other countries in the region. Spillovers are affecting Poland through both real and financial sector channels (Figures 1-3):

- $\quad$ Real sector channel. Export values contracted by 35 percent (year-onyear) in early 2009. While the share of exports in GDP of about

40 percent is relatively low compared to most countries in the region - reflecting the larger size of the Polish economy - the contraction in exports is very large and it is having a significant impact on the economy. GDP growth fell from about 5 percent (year-on-year)

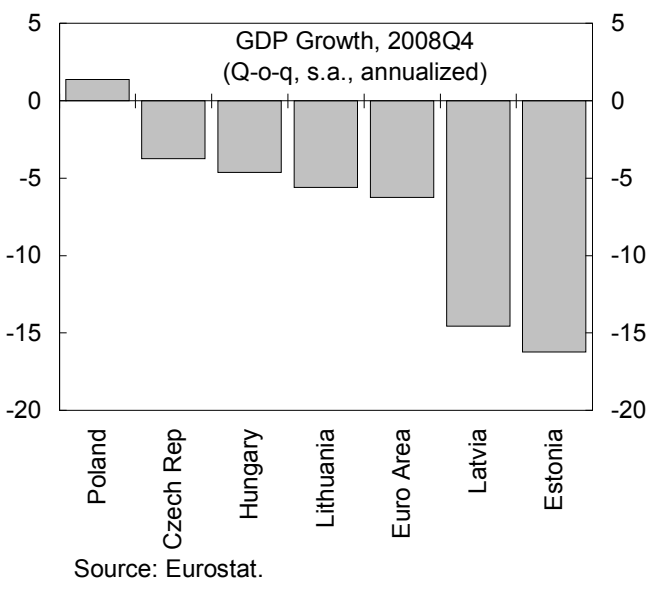
earlier in 2008 to $1 \frac{1}{2}$ percent in the fourth quarter, sustained by relatively robust private consumption growth. High frequency indicators suggest that economic activity has slowed further in the early 2009. Specifically, industrial output declined by about 10 percent.

- $\quad$ Financial sector channel. There is no evidence that foreign banks have begun to reduce exposures to their Polish subsidiaries. Nonetheless, a sharp slowdown in credit growth is underway, as parent banks have significantly curtailed net inflows, which until recently funded about half of credit growth. Indeed, surveys suggest that banks began tightening credit criteria dramatically during the last quarter of 2008, particularly for corporate borrowing. Meanwhile, the interbank market has remained partially frozen despite liquidity-enhancing measures.

\section{But Poland has maintained access to international capital markets. While} sovereign and 5-year CDS spreads have recently eased, they remain about 200 basis points higher than at end-September. The authorities placed a $€ 1$ billion bond at about 300 basis points above German Bunds in January. In addition, Poland's domestic debt market has continued to attract strong demand for government paper, including from foreign investors, who bought a significant share of the Treasury bills and bonds issued during the March auctions. Nevertheless, with FDI coverage of the current account deficit declining rapidly and continued portfolio outflows, the zloty has come under significant pressure, depreciating by about 35 percent against the euro since end-September 2008. 
Figure 1. Poland: Recent Economic Developments, 2001-09

Domestic production fell sharply...

...while trade collapsed...
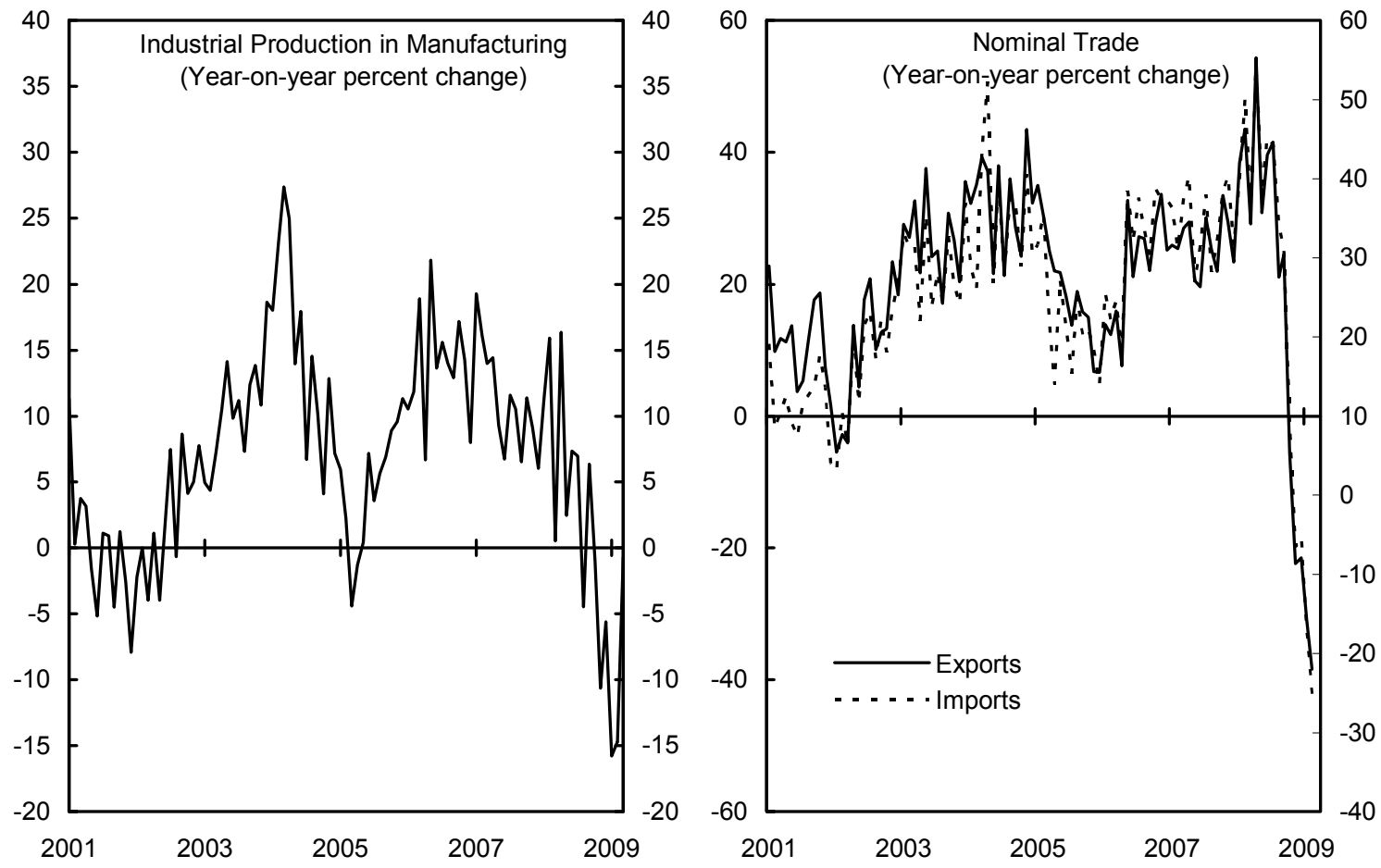

...so as confidence measures...

...but private consumption has held up in positive territory.
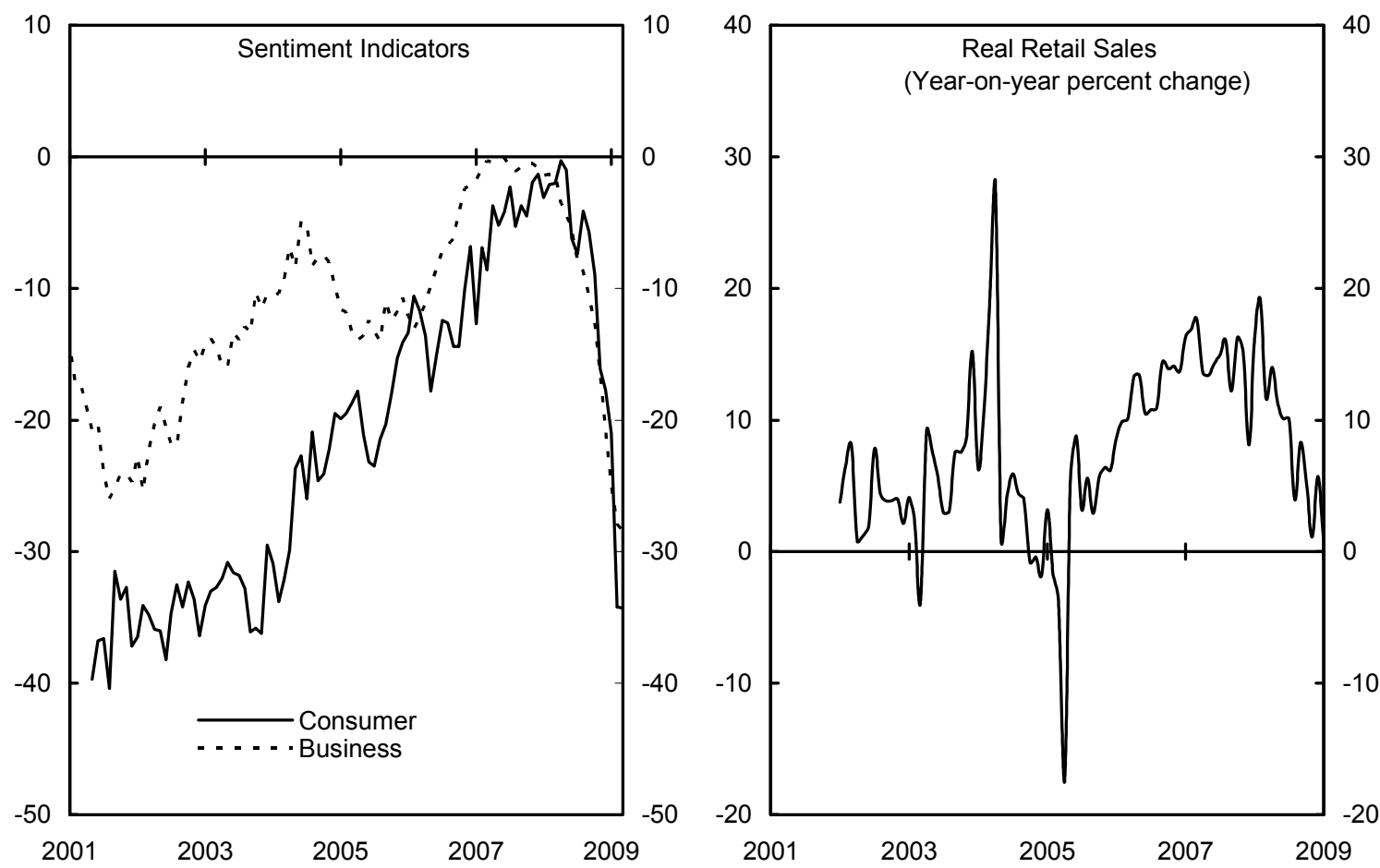

Sources: European Commission; Bloomberg; and Haver. 
Figure 2. Poland: Recent Financial Markets Developments April 2008- April 2009

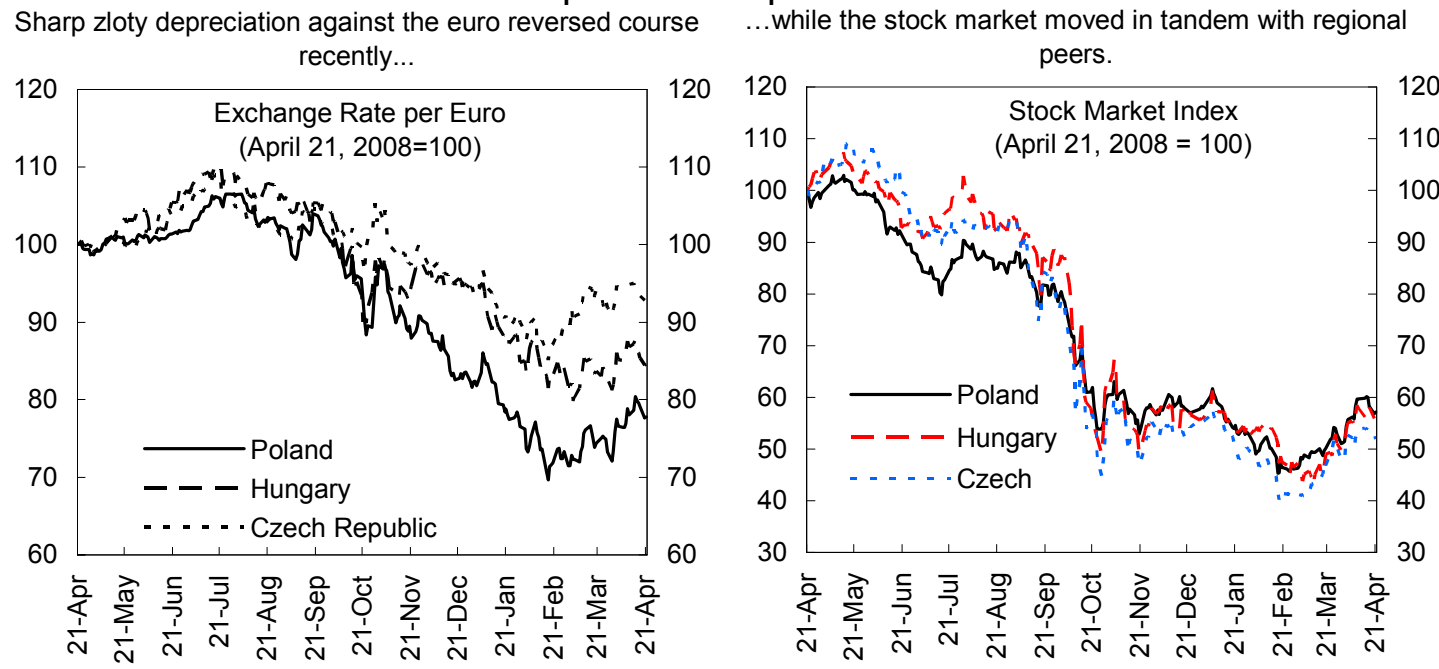

Interbank rates have declined from their 2008 highs...

...while domestic treasury auctions saw healthy demand this year.
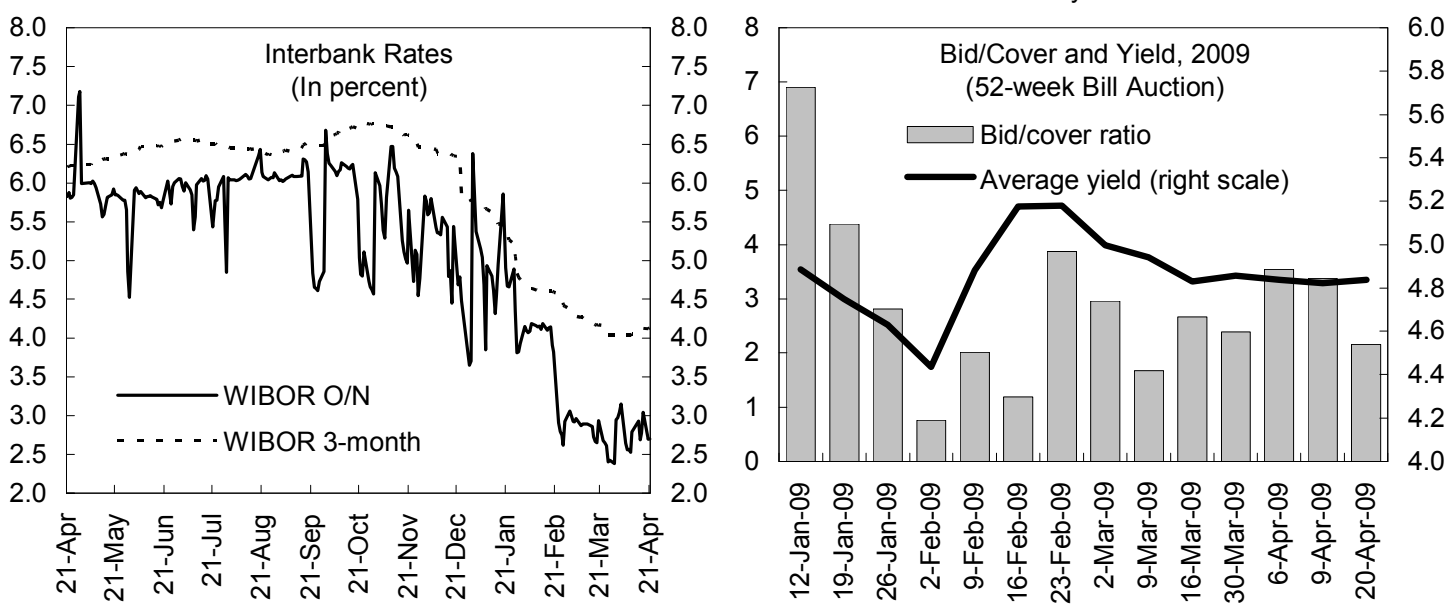

Sovereign bond spreads trended higher, but remain contained relative to CEE peers..

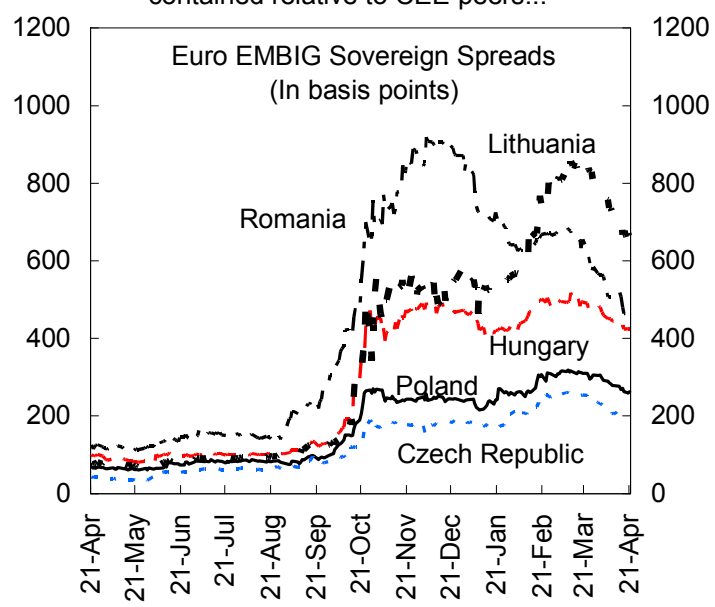

...with similar trends seen in CDS spreads.

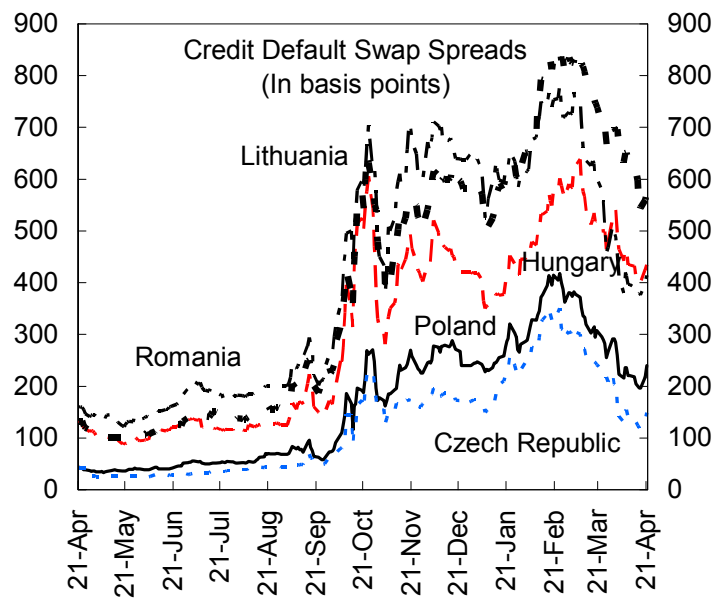

Source: Bloomberg 
Figure 3. Poland: Balance of Payments Developments, 2000-08

CAD/GDP has widened, but remained relatively contained

Net FDI no longer fully covers the CAD
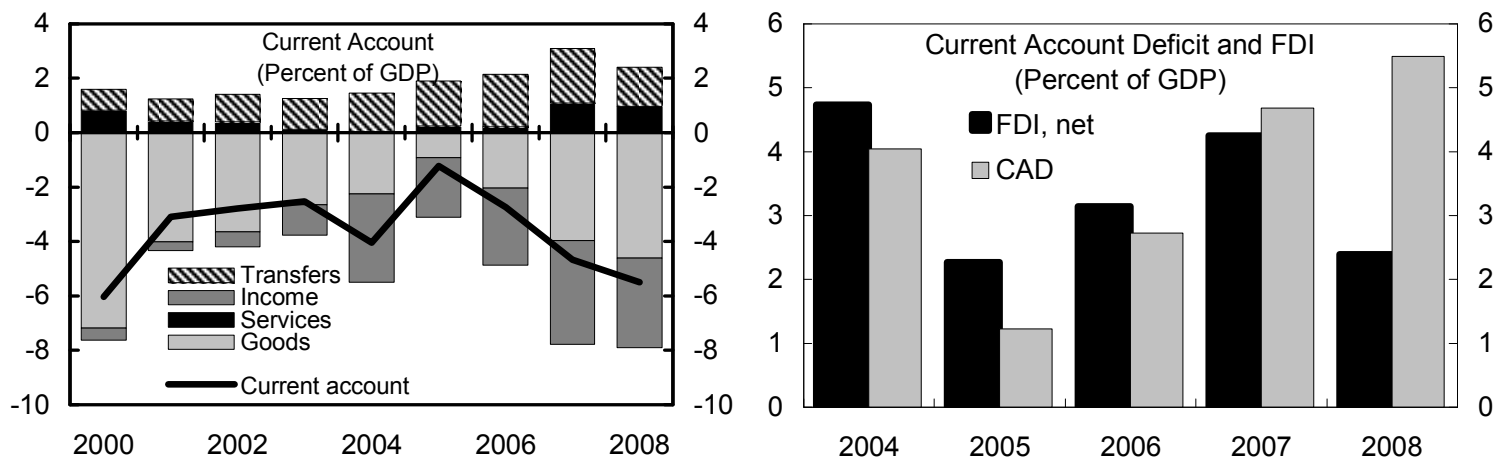

Portfolio outflow by non-residents in 2008 was only partly matched by asset drawdown of Polish residents
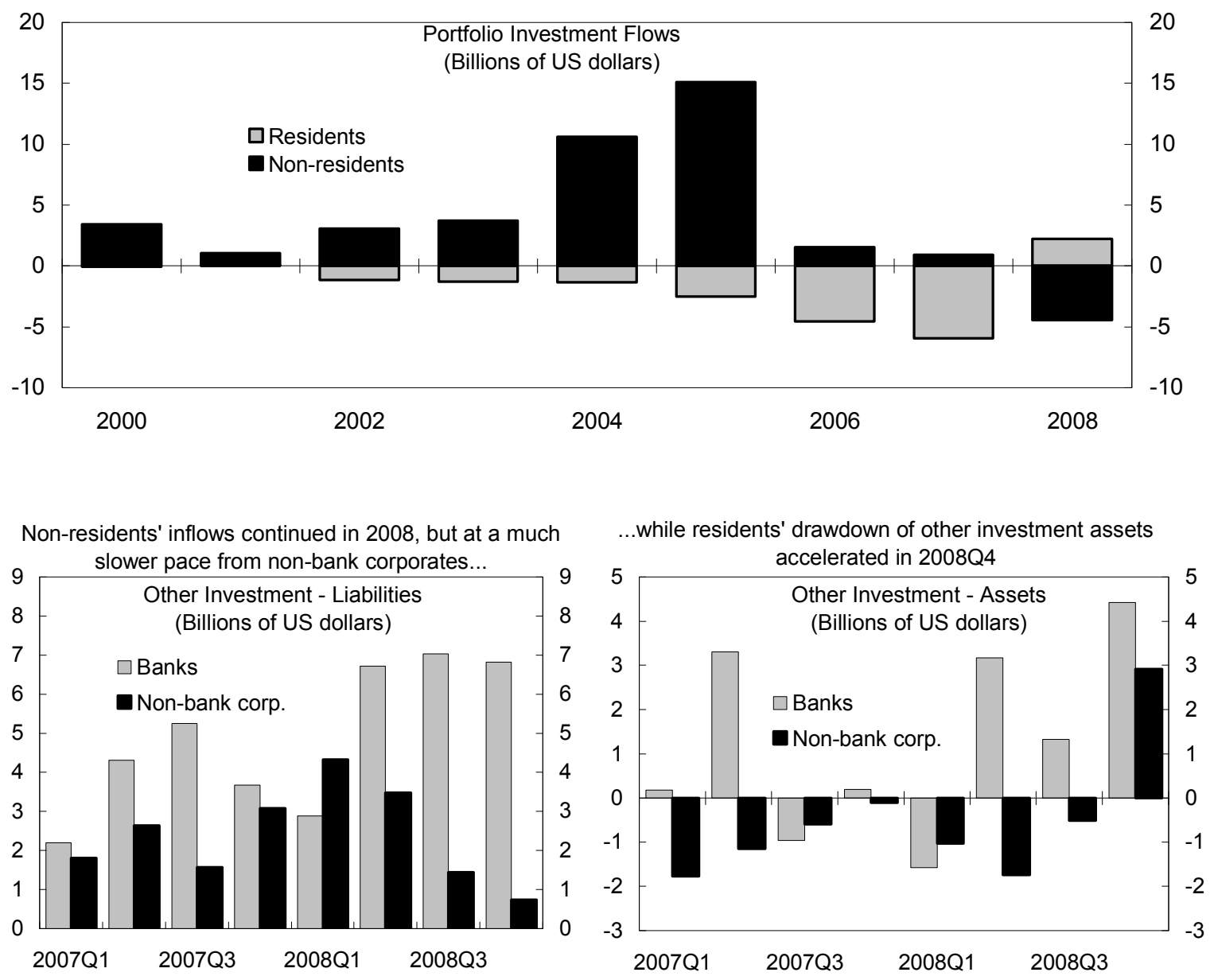

Sources: European Commission; Bloomberg; and Haver. 


\section{Strong Policy Response to the Recent Spillovers}

\section{The authorities have responded in a timely and effective manner to the}

downturn: monetary policy has been easing; financial sector surveillance has intensified, with important pro-active measures; while fiscal policy has balanced short-term cyclical considerations with long-term policy objectives. Specifically,

- Monetary policy: On the basis of cyclical considerations and taking account of euro interest rate cuts, the MPC has embarked on a loosening cycle, reducing policy rates by 225 basis points since November. The most recent cuts were tempered by concerns about pressures on the zloty. The MPC has underscored that it stands ready to cut rates further if downside risks to the economy materialize, while monitoring the exchange rate pass through and potential balance-sheet effects.

- Financial sector. The Polish authorities have been actively safeguarding financial sector stability (Box 1). Notably, to increase domestic liquidity the NBP has arranged dollar, Swiss franc, and euro swaps, widened the list of collateral that can be used at its discount window, and will extend the maturity of repo transactions effective May 1. Moreover, as the interbank market froze late last year, the authorities have proposed to guarantee interbank transactions, although concerns about adverse signaling effects could limit the effectiveness of this. In addition, the frequency of stress testing and on-site inspections has been stepped up to further tailor recommendations to individual banks and, when appropriate, encourage smaller institutions to consolidate.

- Fiscal policy: With a view to adhering to their EU commitments and euro adoption timetable, the authorities remain determined to ensure that the state budget deficit does not exceed the budget limit of zl.18.2 billion in 2009-even though they foresee GDP growth to be significantly weaker than assumed in the budget. They intend to achieve this primarily by cutting expenditure at the state level. While the deficit of the general government will remain above 3 percent of GDP in 2009, in part because of higher deficits at lower levels of government, these pro-cyclical expenditure cuts at the state level will significantly limit the extent to which automatic stabilizers are at play. Thus, at the current juncture, the authorities' concern about the negative implications of a higher nominal deficit for borrowing costs and their euro adoption timetable are outweighing the benefits of allowing a strong counter-cyclical impact through automatic stabilizers. 


\section{Box 1. Measures to Safeguard Financial Sector Stability}

To increase bank's capital buffers

- Encouraged banks to retain earnings to boost own capital. With all profits from 2008 retained, capital-adequacy ratio would increase by 1.5 percentage points.

To provide zloty and foreign currency liquidity

- Weekly three-month (and starting in May, six-month) repo operations have been introduced.

- The range of collateral for Lombard credit has been broadened and haircuts reduced.

- The NBP started providing euro swaps to domestic banks.

- NBP has secured participation in the weekly euro-Swiss franc exchange swap operations of the Swiss National Bank and the Eurosystem.

- A repo line with the ECB of up to $€ 10$ billion has been made available to the NBP.

To intensify financial sector surveillance

- Increased frequency of stress testing and onsite inspections.

- Requested banks to review their lending policy and contingency plans.

- Requested banks to submit daily reports on new exposures to foreign entities.

To promptly issue corrective measures

- $\quad$ Stepped up individual measures towards certain banks. For example, early warnings were issued to some banks to stop mortgage lending in foreign currency when they started experiencing FX funding difficulties.

- Issued recommendations to a couple of small banks to increase their capital base as their CARs were falling close to 8 percent.

- Planned consolidation for small banks that are not viable.

To boost confidence in the system

- The Bank Guarantee Fund law has been amended to increase the level of deposit guarantee from $€ 22,500$ to $€ 50,000$ and eliminate coinsurance.

- A draft law to guarantee interbank lending has been submitted to the parliament. The government has set aside zl. 40 billion for these guarantees.

To increase coordination between agencies

- Frequent meetings of the Financial Stability Committee to discuss issues and measures. The committee was legally established in the fall of 2008 and it is comprised of representatives from the NBP, KNF and MOF.

- The KNF has been in close contact with parent banks and supervisors.

To boost domestic credit

- Increased the capital of state-owned BGK bank by zl. 2 billion enabling it to lend about zl. 20 billion to domestic firms.

- A $\$ 500$ million credit line from the World Bank for Polish SMEs is in the pipeline. 


\section{E. Outlook}

9. Notwithstanding Poland's solid fundamentals and sound policy response, the intensification of adverse spillovers will weigh on the outlook. The authorities are likely to reduce further their forecast for real GDP growth in 2009; in their view, the economy is projected to continue to expand this year, although at a very slow pace. They take confidence from the still robust growth in domestic consumption evident in early 2009. Staff's baseline projection envisages a somewhat sharper slowdown in economic activity, with growth falling from about $4 \frac{3}{4}$ percent in 2008 to about $-3 / 4$ percent in 2009 , reflecting less favorable assumptions about growth in main export markets and the view that domestic demand growth is set to slow notably from its current pace. The projected recovery of growth to about $1 \frac{1}{4}$ percent in 2010 hinges on the realization of current WEO assumptions.

10. Inflation is set to fall further. As world oil prices have fallen and wage developments have tracked real activity, price pressures have eased markedly since last summer, despite the sharp zloty depreciation. With growth well below potential, inflation is projected to remain within its tolerance range for the foreseeable future.

11. The balance of payments is expected to continue to be financed through access to financial markets without undue pressures on the zloty. Declining import volumes and favorable terms of trade developments - weakening commodity prices, notably oil prices will more than offset a projected decline in exports and the current account position is set to gradually improve. While FDI inflows are declining and Poland faces rollover requirements of about $\$ 105$ billion (25 percent of GDP) in 2009, staff's baseline scenario that Poland can continue to satisfy its financing needs through market borrowing.

\section{Risks to the banking sector have increased, but are expected to remain}

manageable. Recent data suggest that banks will remain profitable, with solvency ratios that are declining, but will remain at comfortable levels in 2009. The zloty depreciation has prompted the authorities to revisit foreign current risks in the banking sector through its balance sheet impact on corporates and households. On the corporate side, there have been some concerns regarding FX options that were contracted when the zloty was strong. The vast majority of these derivatives have been found to be associated with export hedging; only a small portion was overhedged because export demand projections have proven optimistic. In these cases, banks have been encouraged to negotiate with their client suitable loan terms and ensured that banks provision for possible losses. On the household side, the authorities have seen no worsening in the quality of banks' FX-denominated mortgage portfolios and this asset class has continued to exhibit the lowest NPL ratios (0.6 percent at end-2008 compared to 4.4 percent for total lending), reflecting offsetting declines in FX-interest rates and earlier regulatory recommendations regarding FX lending. 


\section{Role OF THE FleXible Credit Line ANd ACCESS}

13. To help preserve market access and to guard against downside risks, the authorities have expressed interest in a one-year FCL arrangement, which they intend to treat as precautionary. As explained, access to international capital markets has been preserved so far. However, further deterioration in the global or regional environment risks curtailing such access. By boosting usable reserves - by roughly 30 percent — an FCL on a precautionary basis could help maintain market access and protect against such downside risks during the current period of high volatility and retrenchment in international capital markets (figure 4). The FCL arrangement would complement further financing under discussion with the World Bank, the European Investment Bank and the ECB. ${ }^{3}$

\section{A. Access}

\section{Staff believes that risks to the balance of payments justify access in the requested} amount of SDR13.69 billion (\$20.3 billion, 1000 percent of quota). Under staff's base-line projection, Poland has an external financing requirement of close to $\$ 106$ billion for 2009 , which is expected to be fully covered with only a small drawdown in official reserves, despite a significant fall projected in foreign direct investment. This outcome would be in line with recent developments, not least Poland's continued market access. In staff's view, the likelihood of preserving such access would be significantly bolstered by access to the FCL in the amount of 1000 percent of quota as this would reaffirm to markets the Fund's continued strong endorsement of policies and at the same time provide assurances that the authorities would have the potential reserves needed to deal with a further deterioration in the external environment in the event that downside risks materialize. Indeed, a decline in rollover rates and FDI inflows, a larger current account deficit, or larger capital outflows compared to the base-line scenario could lead to the emergence of a financing gap: staff's adverse scenario entail a potential financing gap of SDR1 1.6 billion (around \$17.5 billion) under plausible but not extreme financing assumptions, notably the assumption that roll-over rates drop to 80-90 percent (Box 2 and Tables 7 and 8). While the proposed level of access is high in terms of quota, relative to other indicators (such as GDP, reserves, exports) it is in line with other high access cases, if not lower.

\footnotetext{
${ }^{3}$ The authorities borrowed $€ 1(\$ 1.25)$ billion from the World Bank in December, 2008 under a DPL in support of the authorities' structural reforms. Two additional World Bank loans_- totaling up to €2 (\$2.5) billion—could be triggered by further structural reforms. The European Investment Bank is expected to boost its lending to Poland, from $€ 2.8$ (\$3.6) billion in 2008 to $€ 5-6$ (\$6.5-7.8) billion this year. The authorities have requested a euro-zloty swap arrangement that is still under review by the ECB.
} 
Figure 4. Poland: Reserve Coverage in International Perspective
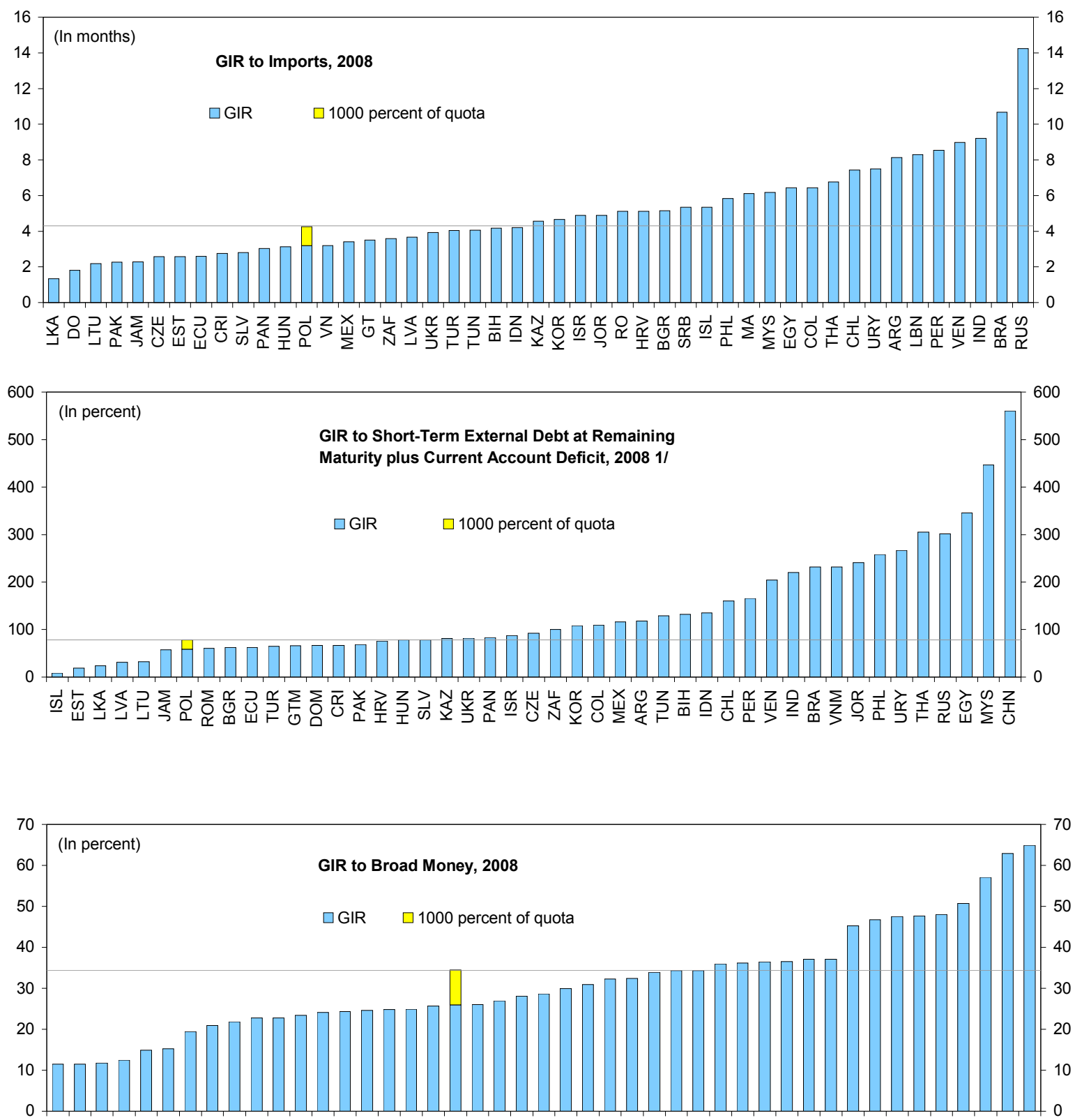

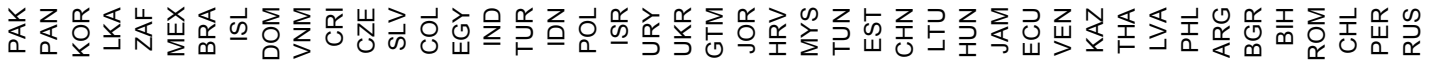

Sources: Haver Analytics; World Economic Outlook; and IMF staff estimates.

$1 /$ GIR at the end of 2008 in percent of ST debt at original maturity at the end of 2008 plus amortization of MLT debt and current account deficit in 2009. The current account is set to zero if it is in surplus. 


\section{Box 2. Access Level}

Under a plausible but not extreme adverse financing scenario, Poland's financing gap is estimated at SDR11.6 billion (around $\$ 17.5$ billion, 847 percent of quota). The main assumptions underlying this scenario are as follows:

- $\quad$ A reduction in FDI of 15 percent with respect to the 2009 baseline and of about 45 percent with respect to 2008 , driven mainly by banking investment;

- $\quad$ Equity portfolio outflows of around 10 percent of total non-resident portfolio holdings, after accounting for valuation effects;

- Implied rollover rates of around 80 percent of short-term debt at remaining maturity, which reflects shortening of maturities as well as potentially higher financing pressures on locally-owned banks and the corporate sector (Table 8);

- Other investment outflows - mostly from non-resident deposits-for $\$ 2.5$ billion;

- Drawdown of private foreign assets - mainly by banks but also, to a lesser extent, by the corporate sector-for 10 percent of total liquid assets; no drawdown of official reserves from current level.

Even though these assumptions draw on staff projections, market analysts' views, and past as well as current crisis episodes, they are subject to a high degree of uncertainty. Nevertheless, they take account of both the worsening external environment and the very strong country-specific policies and fundamentals. The proposed access level of SDR13.69 billion allows for a further cushion of about SDR2 billion.

Economic concept-based metrics for Poland's potential access of SDR13.69 billion are in line with access under previous Fund arrangements.

Poland: Proposed Access, 2009

\begin{tabular}{|c|c|c|c|c|c|c|c|}
\hline & \multirow[b]{2}{*}{$\begin{array}{c}\text { Proposed } \\
\text { Arrangement }\end{array}$} & \multirow[b]{2}{*}{$\begin{array}{c}\text { Mexico } \\
\text { Arrangement }\end{array}$} & \multicolumn{5}{|c|}{ High-Access Cases 1/ } \\
\hline & & & $\begin{array}{c}\text { Proposed } \\
\text { Arrangement } \\
\text { (Percentile) }\end{array}$ & $\frac{\begin{array}{c}\text { 20th } \\
\text { Percentile }\end{array}}{\text { (Ra }}$ & $\begin{array}{l}\text { 80th } \\
\text { Percentile } \\
\text { atio) }\end{array}$ & Average & Median \\
\hline \multicolumn{8}{|l|}{ Access } \\
\hline In millions of SDRs & 13,690 & 31,528 & 82 & 1,579 & 13,291 & 8,339 & 6,901 \\
\hline Average annual access & 1,000 & 1,000 & 97 & 142 & 508 & 322 & 248 \\
\hline \multicolumn{8}{|l|}{ Total access in percent of: $2 /$} \\
\hline Actual quota & 1,000 & 1,000 & 82 & 300 & 941 & 639 & 505 \\
\hline Calculated quota & 662 & 672 & 66 & 273 & 918 & 600 & 545 \\
\hline Gross domestic product & 5 & 6 & 46 & 2.9 & 8.8 & 8.3 & 5.6 \\
\hline Gross international reserves & 35 & 49 & 24 & 28 & 88 & 82 & 50 \\
\hline Exports of goods and nonfactor service & 11 & 19 & 24 & 10.8 & 39.0 & 30.4 & 20.7 \\
\hline Imports of goods and nonfactor service & 11 & 17 & 22 & 10.9 & 44.3 & 29.9 & 19.8 \\
\hline \multicolumn{8}{|l|}{ Total debt stock } \\
\hline Public & 10 & 10 & 36 & 7 & 31 & 21 & 12 \\
\hline External & 8 & 24 & 30 & 6 & 17 & 13 & 12 \\
\hline Short-term external $3 /$ & 21 & 77 & 26 & 20 & 77 & 97 & 32 \\
\hline M2 & 11 & 10 & 30 & 8 & 25 & 25 & 13 \\
\hline \multicolumn{8}{|c|}{ Source: Executive Board documents, MONA database, and Fund staff estimates. } \\
\hline \multicolumn{8}{|c|}{$\begin{array}{l}\text { 1/ High access cases include available data at approval and on augmentation for all the requests to the Board since } 1995 \text { which } \\
\text { involved the use of the exceptional circumstances clause or SRF resources. Exceptional access augmentations are counted as } \\
\text { separate observations. For the purpose of measuring access as a ratio of different metrics, access includes augmentations and } \\
\text { previously approved and drawn amounts. Includes Mexico's request for FCL in amount of } 1000 \% \text { of quota. } \\
2 \text { / The data used to calculate ratios is the actual value for the year prior to approval for public and short-term debt, and the projection } \\
\text { at the time of program approval for the year in which the program was approved for all other variables } \\
\text { 3/ Refers to residual maturity. }\end{array}$} \\
\hline
\end{tabular}




\section{B. Qualification Criteria}

15. Staff believes that Poland fully meets the qualification criteria. Economic fundamentals and the institutional policy framework are very strong; the authorities have a sustained track record of very strong and timely policy implementation, and they remain committed to maintaining such policies in the future. Taken together, these give confidence that Poland will respond appropriately to any balance of payments difficulties it could encounter. As to the relevant criteria for assessing qualification for an FCL arrangement identified in $\mid 2$ of the FCL decision, staff's assessment is as follows (Figures 5-7):

- A sustainable external position: Notwithstanding the EU accession-related investment boom, the stock of external debt has remained at a sustainable level of around 40-50 percent of GDP, with a shift in its composition from the government to the private sector. The sustainability of the external debt position over the medium term is robust to stress scenarios. The build up of external liabilities has been matched by increased holdings of foreign assets. The current account deficit, as a percentage of GDP, is relatively low, not least compared with CEE peers.

- A capital account position dominated by private flows: Except for EU transfers, and limited borrowing from multilateral development banks, the vast majority of capital flows to Poland originate from the private sector.

- A track record of steady sovereign access to international capital markets at favorable terms: Poland has continued to enjoy high credit ratings over the past decade, with investment grade since 1999, and has maintained such ratings despite the current crisis in the region. The recent peak in sovereign spreads on both local and foreign currency debt, from low and stable levels, is in line with global and regional trends. As recently as January 2009, Poland was able to issue sovereign debt in international capital markets.

- A reserve position that is relatively comfortable when the FCL is requested on a precautionary basis: Reserves have reached a comfortable level relative to most standard metrics. However, the reserve coverage relative to shortterm external debt, while adequate in normal times, calls for increased buffers in the current environment of high volatility and global deleveraging.

- $\quad$ Sound public finances, including a sustainable public debt position: As a share of GDP, public debt has declined in recent years to around 45 percent of GDP and is on a sustainable path. Beyond the authorities' strong commitment to the Maastricht criteria, fiscal policy has been underpinned by the Polish Public Finance Act - prompting corrective action when public debt reaches trigger levels of 50 and 55 percent of GDP - and by the Constitutional ceiling on public debt of 60 percent of GDP. 
- Low and stable inflation, in the context of a sound monetary and exchange rate policy framework: A disciplined and transparent inflation targeting framework has built policy credibility and allowed a steady disinflationary path. More recently, timely and credible policy reaction to renewed inflationary pressures helped headline inflation fall back inside the tolerance range.

- The absence of bank solvency problems that pose an immediate threat of a systemic banking crisis: The system has been spared any direct impact of the crisis and Poland's banking system remains relatively well capitalized. Non-performing loans have fallen sharply in recent years, while bank profitability has been robust throughout 2008. However, as the economy contracts and the crisis deepens, credit risks are rising, but are expected to be manageable.

- $\quad$ Effective financial sector supervision: The supervisory framework has been further strengthened in line with the recommendations of the 2006 FSAP Update and the unification of all supervisors under the auspices of the KNF. The Polish authorities thus have an adequate supervisory, legal, and institutional framework to promptly intervene in banks if needed. The NBP has in place a procedure for emergency liquidity assistance. Operational coordination between the ministry of finance, the NBP and the KNF on financial stability and crisis management has been formalized in 2008 .

- Data transparency and integrity: Poland subscribed to the SDSS in 1996 and the overall quality of Polish data is good. ${ }^{4}$ The 2003 data ROSC indicates that Poland meets the prerequisites for high quality data.

\footnotetext{
${ }^{4}$ The statistical authorities are analyzing the sources of the sharp increase in errors and omissions in the balance of payments in the last two years. One possible source of this increase is an underreporting in the "other investment" category in the financial accounts.
} 
Figure 5. Poland: Qualification Criteria

Sustainable external position

Diversified composition of external debt
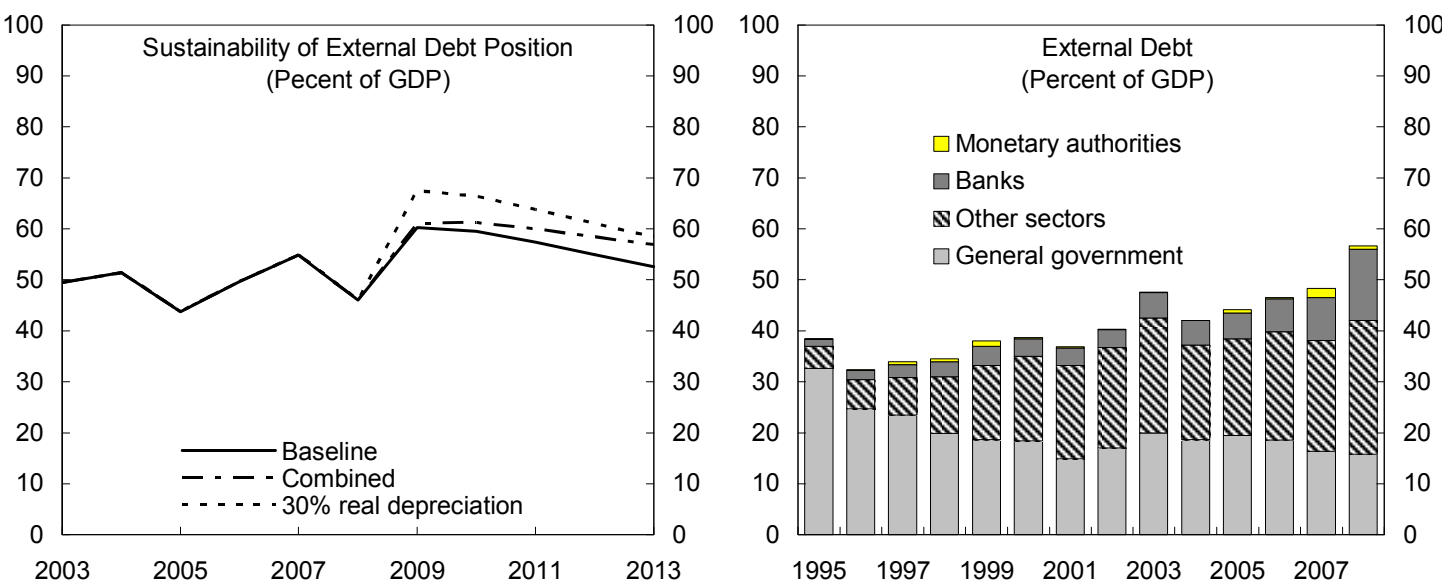

Steady sovereign access to capital markets

Relatively comfortable reserves position
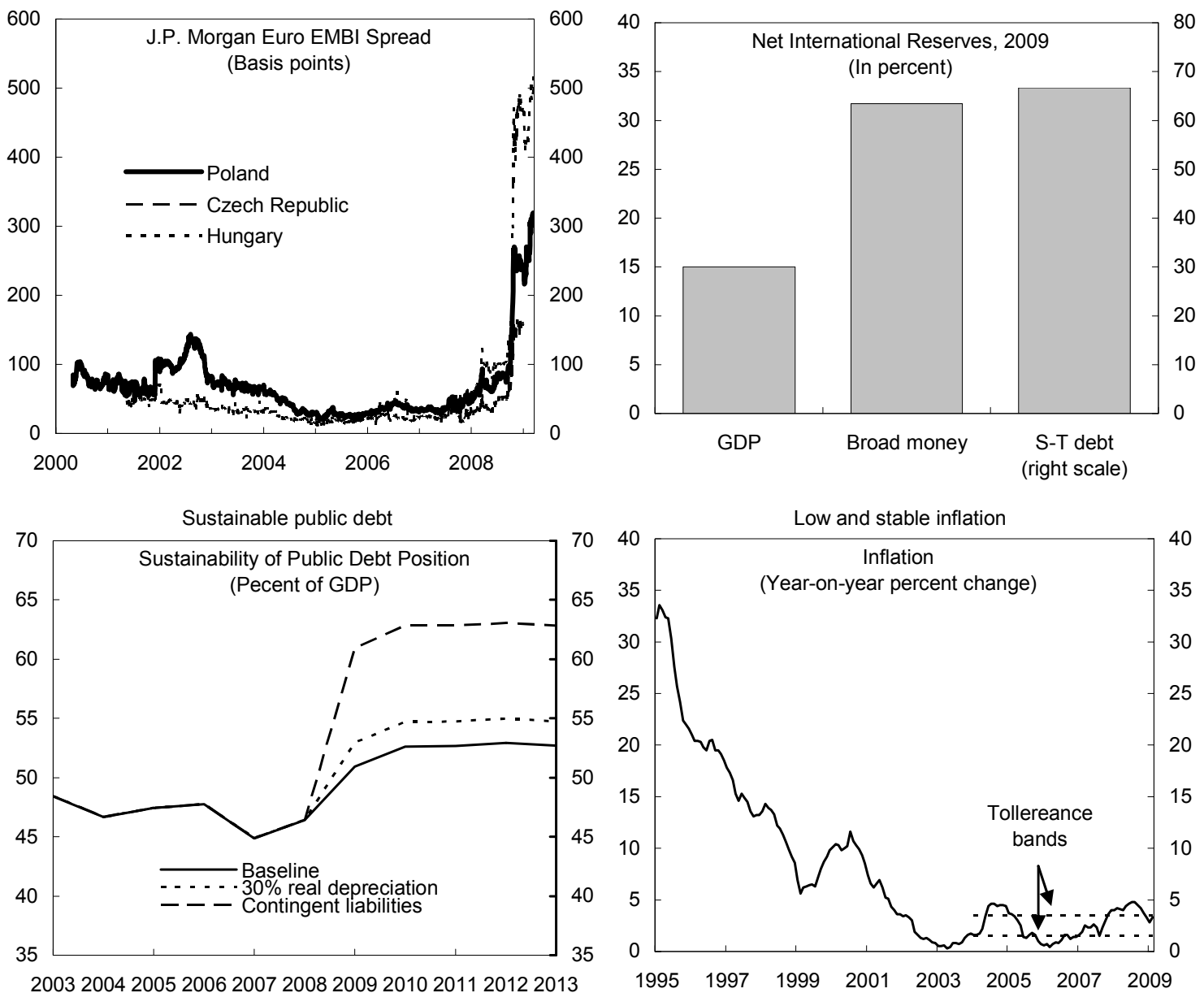

Sources: Bloomberg L. P.; national authorities; and staff estimates. 
Figure 6. Poland: External Debt Sustainability: Bound Tests 1/ (External debt in percent of GDP)

External debt, as a share of GDP, has risen but is sustainable over the long-run and can withstand a variety of shocks
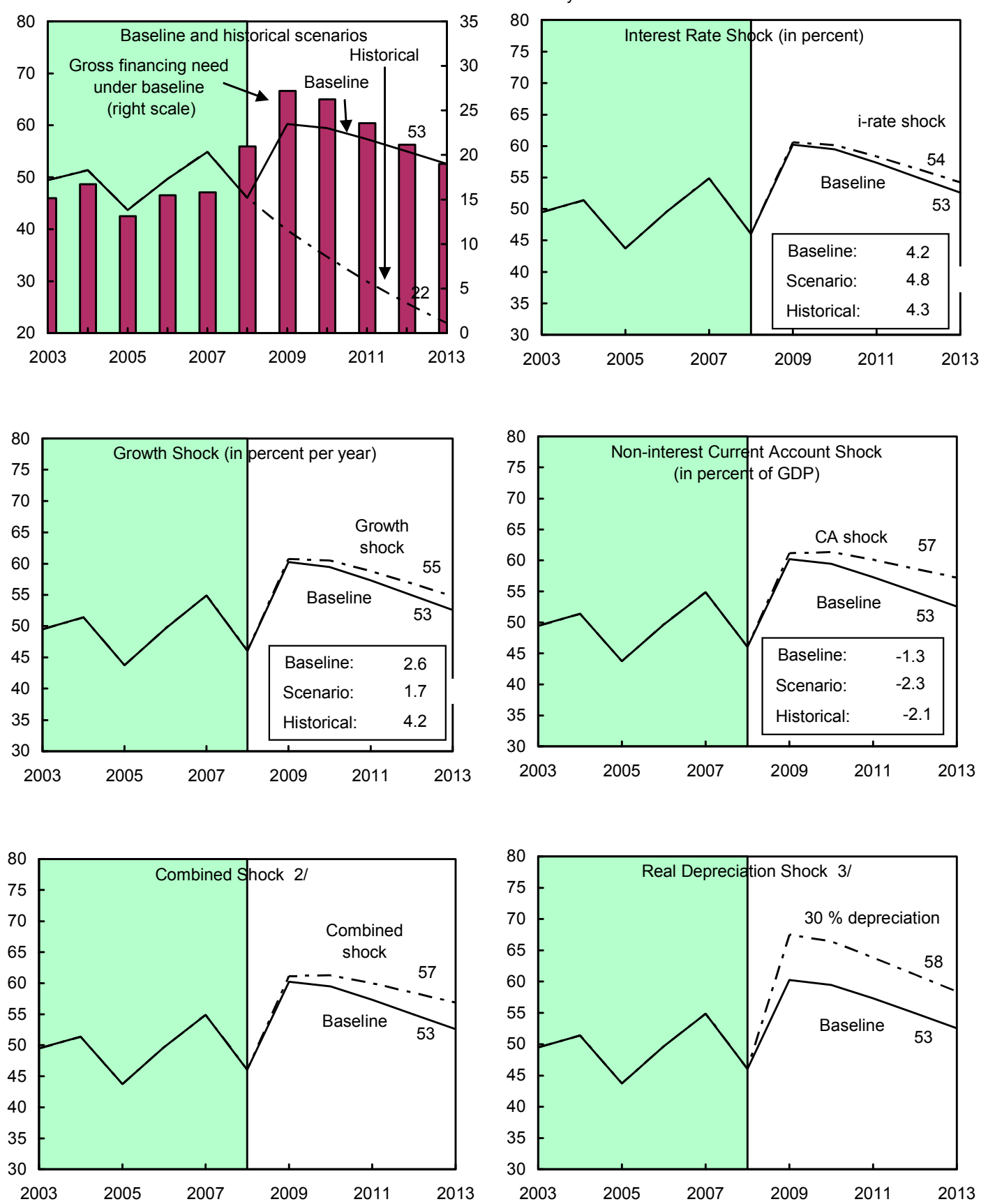

Sources: International Monetary Fund; Polish authorities; and IMF staff estimates.

1/ Shaded areas represent actual data. Individual shocks are permanent one-half standard deviation shocks. Figures in the boxes represent average projections for the respective variables in the baseline and scenario being presented. Ten-year historical average for the variable is also shown.

2/ Permanent 1/4 standard deviation shocks applied to real interest rate, growth rate, and current account balance.

3/ One-time real depreciation of 30 percent occurs in 2009. 
Figure 7. Poland: Public Debt Sustainability: Bound Tests 1/ (Public debt in percent of GDP)

Baseline and historical scenarios

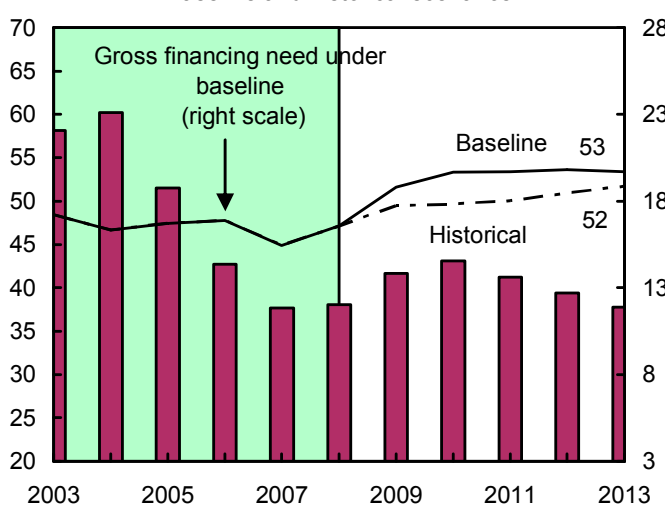

Growth Shock (in percent per year)

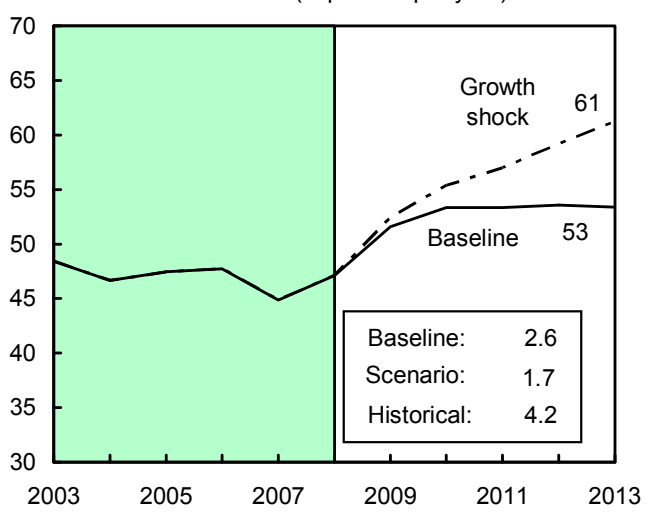

Combined Shock $2 /$

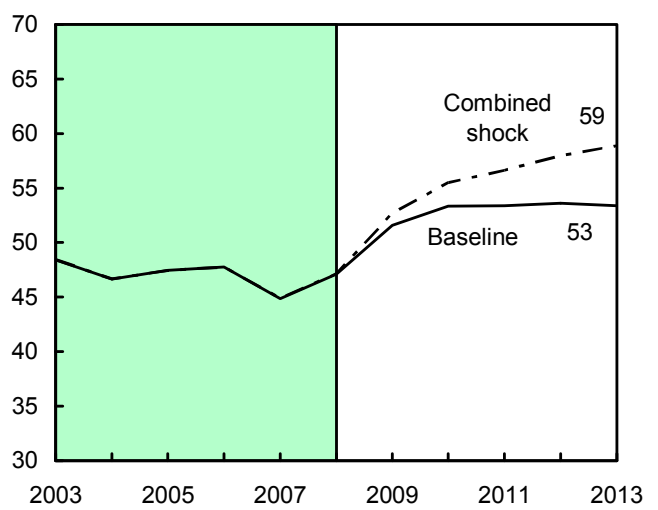

Interest Rate Shock (in percent)

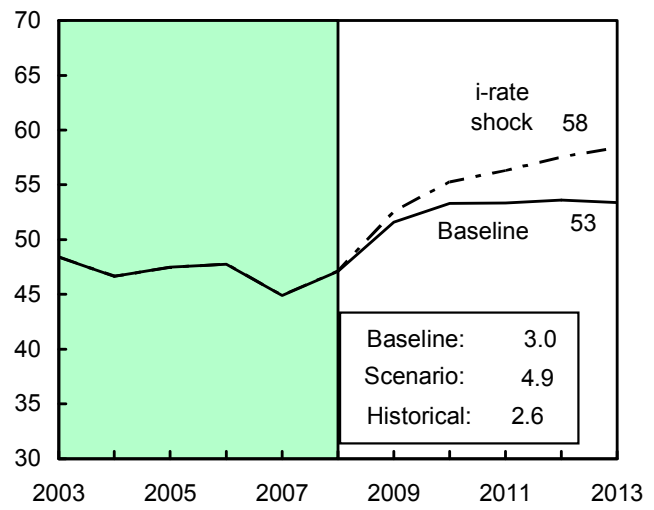

Primary Balance Shock and No Policy Change Scenario

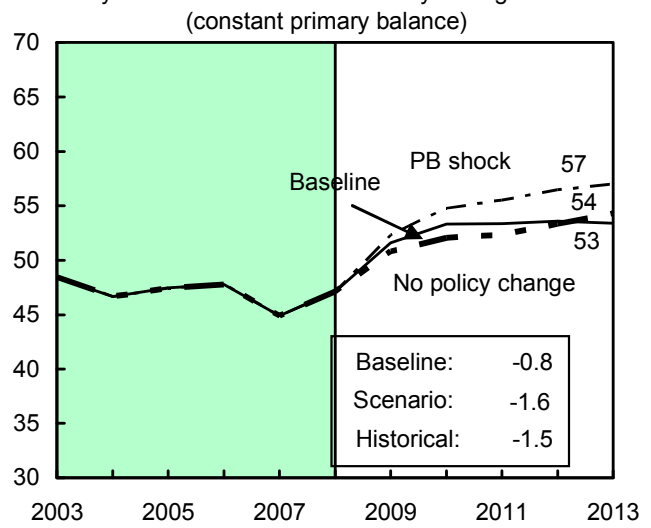

Real Depreciation and Contingent

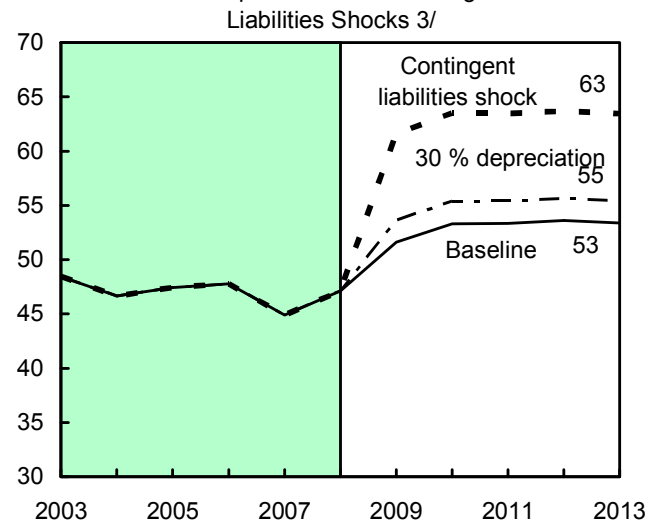

Sources: International Monetary Fund; Polish authorities; and IMF staff estimates.

1/ Shaded areas represent actual data. Individual shocks are permanent one-half standard deviation shocks. Figures in the boxes represent average projections for the respective variables in the baseline and scenario being presented. Ten-year historical average for the variable is also shown.

2/ Permanent 1/4 standard deviation shocks applied to real interest rate, growth rate, and primary balance.

3 / One-time real depreciation of 30 percent and 10 percent of GDP shock to contingent liabilities occur in 2009, with real depreciation defined as nominal depreciation (measured by percentage fall in dollar value of local currency) minus domestic inflation (based on GDP deflator). 


\section{IMPACT ON FUND FINANCES, RISKS, AND SAFEGUARDS}

16. Fund's liquidity is expected to remain adequate after approval of an FCL arrangement for Poland. The impact of the proposed FCL of 1000 percent of quota (SDR 13.69 billion) on the Fund's finances and liquidity position would be manageable (see Supplement I).

17. Poland's capacity to repay the Fund is strong. The authorities have indicated that they intend to treat the arrangement as precautionary. Nevertheless, even if a full drawing under the FCL were made Poland's capacity to fulfill its financial obligations to the Fund would not be an issue. Poland has an excellent track record of meeting its obligations to the Fund, the government has a deep commitment to macroeconomic stability and prudent fiscal policies and the economy's medium-term growth prospects remain strong. Moreover, even if the adverse scenario were to materialize, Poland's external debt would remain on a sustainable medium-term path notwithstanding the peak in debt service due on GRA credit in 2013.

18. In line with the Fund's safeguards policy under the FCL, the authorities have authorized Fund staff to have access to the most recently completed independent annual audit of the NBP's financial statements. The NBP already publishes its balance sheet on a monthly basis on its website. 5 The authorities indicated that they will provide Fund staff with all the needed additional information and that the NBP and its external auditors will discuss with them the audit findings.

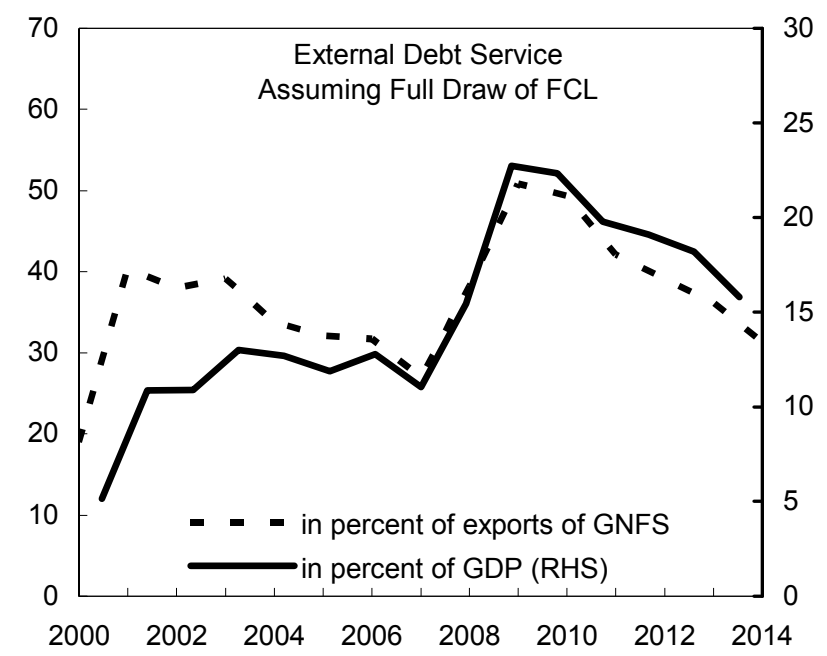

\footnotetext{
${ }^{5}$ http://www.nbp.pl/statystyka/Pieniezna_i_bankowa/DWN/bilans_nbp.xls
} 
Poland: Indicators of Fund Credit, 2008-14

\begin{tabular}{|c|c|c|c|c|c|c|c|}
\hline & \multirow[b]{2}{*}{2008} & \multicolumn{6}{|c|}{ Projections } \\
\hline & & 2009 & 2010 & 2011 & 2012 & 2013 & 2014 \\
\hline \multicolumn{8}{|l|}{ Stocks from prospective drawings $1 /$} \\
\hline Fund credit in millions SDR & - & 13,690 & 13,690 & 13,690 & 10,268 & 3,423 & - \\
\hline in percent of quota & - & 1,000 & 1,000 & 1,000 & 750 & 250 & - \\
\hline in percent of GDP & - & 5 & 5 & 5 & 3 & 1 & - \\
\hline in percent of exports of goods and services & - & 11 & 11 & 10 & 7 & 2 & - \\
\hline in percent of gross reserves $2 /$ & - & 34 & 33 & 31 & 22 & 6 & - \\
\hline \multicolumn{8}{|l|}{ Flows from prospective drawings 3 / } \\
\hline GRA Charges & - & 99 & 197 & 197 & 191 & 111 & 18 \\
\hline Level Based Surcharge & & 104 & 205 & 205 & 197 & 85 & 2 \\
\hline Service Charges & - & 68 & - & - & - & - & - \\
\hline Principal & - & - & - & - & 3,423 & 6,845 & 3,423 \\
\hline Debt Service due on GRA credit (millions SDR) & - & 271 & 402 & 402 & 3,810 & 7,041 & 3,443 \\
\hline in percent of quota & - & 20 & 29 & 29 & 278 & 514 & 251 \\
\hline in percent of GDP & - & 0 & 0 & 0 & 1 & 2 & 1 \\
\hline in percent of exports of goods and services & - & 0 & 0 & 0 & 3 & 4 & 2 \\
\hline in percent of gross reserves $2 /$ & - & 1 & 1 & 1 & 8 & 13 & 6 \\
\hline \multicolumn{8}{|l|}{ Memo Item: } \\
\hline Total external debt, assuming full drawing (in percent of GDP) & 46 & 65 & 64 & 62 & 58 & 54 & 50 \\
\hline
\end{tabular}

Sources: IMF Finance Department; Polish authorities; and IMF staff estimates.

1/ End of Period. Assumes full drawing under the FCL upon approval. The Polish authorities have expressed their intention to treat the arrangement as precautionary. At an SDR/USD rate of 0.667878 as of April 15, 2009.

2/ Excludes IMF purchases.

3 / Based on the rate of charge as of end-March 2009. Includes surcharges under the system currently in force and service charges.

\section{StAFF Appraisal}

19. Staff assesses that Poland fully meets the criteria for an FCL. The very strong policy record, including the response to spillovers from the ongoing global crisis, suggests that the authorities will respond forcefully, effectively and in a timely manner to a further deterioration in the economic environment. The very strong legislative and institutional policy framework, including the anchors provided by the EU membership and Poland's aspirations regarding euro adoption, provide further assurances about the future course of policies. This, together with a relatively low level of indebtedness and Poland's still considerable potential for catch-up gains in productivity and attendant rapid convergence with EU income levels, suggest that the risk to the Fund are well contained.

\section{Staff assesses that an FCL arrangement of the requested amount could help} preserve market access and safeguard against downside risks. Contrary to most regional peers, Poland has preserved market access and continued to tap international capital markets, although at somewhat elevated interest rates. This is evidence of its favorable fundamentals and strong policy record, but it also underscores that Poland is not immune to a further deterioration in the global and regional environment. Indeed, risks in this regard might still be tilted to the downside. In this situation, by signaling that the Fund continues to endorse strongly Poland's economic policies and by augmenting potential reserves, the requested FCL could provide an important boost to confidence and mitigate adverse risks. In addition, given Poland's size in the region, the FCL may provide insurance not only to Poland but to the region more broadly. Staff fully supports Poland's FCL request. 
Table 1. Poland: Selected Economic Indicators, 2005-10

\begin{tabular}{|c|c|c|c|c|c|c|}
\hline & 2005 & 2006 & 2007 & $\begin{array}{l}2008 \\
\text { Prelim. }\end{array}$ & $\begin{array}{l}2009 \\
\text { Proj. }\end{array}$ & $\begin{array}{r}2010 \\
\text { Proj. }\end{array}$ \\
\hline \multicolumn{7}{|l|}{ Activity and prices } \\
\hline GDP (change in percent) & 3.6 & 6.2 & 6.7 & 4.8 & -0.7 & 1.3 \\
\hline Domestic demand & 2.5 & 7.3 & 8.6 & 5.0 & -0.1 & 1.7 \\
\hline Private consumption growth & 2.1 & 5.0 & 5.0 & 5.3 & 1.0 & 1.5 \\
\hline Public consumption growth & 5.2 & 6.1 & 3.7 & 0.0 & 2.0 & 2.0 \\
\hline Domestic fixed investment growth & 6.5 & 14.9 & 17.6 & 7.9 & -4.5 & 2.5 \\
\hline Net external demand (contribution to growth) & 1.1 & -1.1 & -2.1 & -0.3 & -0.6 & -0.5 \\
\hline \multicolumn{7}{|l|}{$\mathrm{CPI}$ inflation (change in percent) } \\
\hline Average & 2.1 & 1.0 & 2.5 & 4.2 & 2.1 & 2.6 \\
\hline End of period & 0.7 & 1.4 & 4.0 & 3.3 & 1.8 & 2.8 \\
\hline Unemployment rate (average, according to Labor Force Survey) & 17.7 & 13.8 & 9.6 & 7.7 & 8.1 & 8.6 \\
\hline Gross domestic saving (ratio to GDP) $1 /$ & 18.4 & 19.0 & 20.7 & 20.4 & 20.3 & 21.1 \\
\hline Gross domestic investment (ratio to GDP) & 19.3 & 21.1 & 24.3 & 24.7 & 22.9 & 23.1 \\
\hline \multicolumn{7}{|l|}{ Public finances (percent of GDP) } \\
\hline General government revenues & 39.1 & 39.8 & 40.0 & 39.2 & 39.3 & 39.8 \\
\hline General government expenditures 2/ & 43.0 & 43.7 & 42.0 & 43.1 & 43.6 & 44.0 \\
\hline General government balance 2/ & -3.9 & -3.9 & -2.0 & -3.9 & -4.3 & -4.2 \\
\hline according to ESA95 & -4.3 & -3.8 & -1.9 & -3.9 & $\ldots$ & $\ldots$ \\
\hline Public debt & 47.5 & 47.8 & 44.9 & 47.1 & 51.6 & 53.3 \\
\hline according to ESA95 & 47.1 & 47.7 & 44.9 & 47.1 & $\ldots$ & $\ldots$ \\
\hline \multicolumn{7}{|l|}{ Money and credit } \\
\hline Private credit (12-month change) & 12.6 & 22.9 & 29.5 & 33.9 & $\ldots$ & $\ldots$ \\
\hline Broad money (12-month change) & 13.1 & 16.0 & 13.4 & 17.5 & $\ldots$ & $\ldots$ \\
\hline Money market rate (eop) & 4.6 & 4.2 & 5.7 & 5.3 & & $\ldots$ \\
\hline Policy Rate 3/ & 4.5 & 4.0 & 5.0 & 5.0 & 3.75 & $\ldots$ \\
\hline Corporate lending rate ( 1 year) 4 / & 7.1 & 5.9 & 6.1 & 7.5 & $\ldots$ & $\ldots$ \\
\hline \multicolumn{7}{|l|}{ Balance of payments } \\
\hline Current account balance (transactions, millions U.S. dollars) & $-3,705$ & $-9,200$ & $-20,100$ & $-29,029$ & $-18,034$ & $-15,957$ \\
\hline Percent of GDP & -1.2 & -2.7 & -4.7 & -5.5 & -4.5 & -3.9 \\
\hline C/A balance plus net FDI, percent of GDP & 1.1 & 0.2 & -0.5 & -3.1 & -2.7 & -2.0 \\
\hline Exports of Goods (millions U.S. dollars) & 96,395 & 117,468 & 145,337 & 177,278 & 150,663 & 155,939 \\
\hline Export volume growth & 8.0 & 14.6 & 9.1 & 5.8 & -6.0 & 0.1 \\
\hline Imports of Goods (millions U.S. dollars) & 99,161 & 124,474 & 162,394 & 201,655 & 159,420 & 166,350 \\
\hline Import volume growth & 4.7 & 17.3 & 13.6 & 6.2 & -4.0 & 1.1 \\
\hline Net oil imports (millions U.S. dollars) & $\ldots$ & $\ldots$ & $\ldots$ & $\ldots$ & & \\
\hline Terms of trade (index $1995=100$ ) & 97.5 & 97.2 & 98.9 & 97.4 & 106.9 & 107.2 \\
\hline FDI, net (in percent of GDP) & 2.3 & 2.9 & 4.2 & 2.5 & 1.8 & 1.8 \\
\hline Official reserves (millions U.S. dollars) & 42,571 & 48,484 & 65,746 & 62,180 & 61,137 & 62,518 \\
\hline months of imports (goods) & 5.2 & 4.7 & 4.9 & 3.7 & 4.6 & 4.5 \\
\hline Total external debt (millions U.S. dollars) & 132,927 & 169,636 & 233,075 & 242,057 & 242,718 & 244,218 \\
\hline Percent of GDP & 43.7 & 49.6 & 54.9 & 46.0 & 60.2 & 59.5 \\
\hline \multicolumn{7}{|l|}{ Exchange rate } \\
\hline Exchange rate regime & Floating & & & & & \\
\hline Zloty per US\$, period average $5 /$ & 3.23 & 3.10 & 2.77 & 2.41 & 3.38 & \\
\hline Zloty per Euro, period average 5/ & 4.03 & 3.90 & 3.79 & 3.52 & 4.40 & $\ldots$ \\
\hline Real effective exchange rate (INS, CPI based) 6/ & 136.2 & 139.2 & 144.6 & 159.0 & $\ldots$ & $\cdots$ \\
\hline percent change & 11.7 & 2.2 & 3.9 & 9.9 & & $\ldots$ \\
\hline
\end{tabular}

Sources: Polish authorities; and IMF staff estimates.

$1 /$ Derived as total savings minus the current account minus capital transfers.

2/ IMF definition (including pension reform costs); estimates assume full execution of EU Fund spending in the

2009 budget, amounting to 2.5 percent of GDP.

3/ NBP Reference Rate. For 2009, latest.

4/ Annual average.

5/ For 2009, exchange rate as of April 22.

$6 /$ Annual average $(1995=100)$. 
Table 2. Poland: Balance of Payments on Transaction Basis, 2005-10 (In millions of US\$)

\begin{tabular}{|c|c|c|c|c|c|c|}
\hline & 2005 & 2006 & 2007 & $\begin{array}{r}2008 \\
\text { Prelim. }\end{array}$ & $\begin{array}{l}2009 \\
\text { Proj. }\end{array}$ & $\begin{array}{l}2010 \\
\text { Proj. }\end{array}$ \\
\hline Current account balance & $-3,705$ & $-9,200$ & $-20,100$ & $-29,029$ & $-18,034$ & $-15,957$ \\
\hline percent of GDP & -1.2 & -2.7 & -4.7 & -5.5 & -4.5 & -3.9 \\
\hline Trade balance & $-2,766$ & $-7,006$ & $-17,057$ & $-24,377$ & $-8,758$ & $-10,410$ \\
\hline percent of GDP & -0.9 & -2.1 & -4.0 & -4.6 & -2.2 & -2.5 \\
\hline \multicolumn{7}{|l|}{ Exports } \\
\hline percentage change in unit values & 18.2 & 22.5 & 26.1 & 22.2 & -15.0 & 3.5 \\
\hline percentage volume growth & 8.0 & 14.6 & 9.1 & 5.8 & -6.0 & 0.1 \\
\hline export market growth & 8.6 & 12.6 & 8.7 & 4.1 & -8.2 & 1.8 \\
\hline \multicolumn{7}{|l|}{ Imports } \\
\hline percentage change in unit values & 13.7 & 25.8 & 29.2 & 24.5 & -20.9 & 4.3 \\
\hline percentage volume growth & 4.7 & 17.3 & 13.6 & 6.2 & -4.0 & 1.1 \\
\hline growth in domestic demand & 2.5 & 7.3 & 8.6 & 5.0 & -0.1 & 1.7 \\
\hline Terms of trade percentage change & 0.8 & -0.3 & 1.7 & -1.5 & 9.7 & 0.3 \\
\hline Services balance & 738 & 753 & 4,718 & 5,006 & 6,060 & 6,069 \\
\hline Credit & 16,258 & 20,584 & 28,790 & 35,457 & 30,134 & 31,189 \\
\hline Debit & 15,520 & 19,831 & 24,072 & 30,451 & 24,073 & 25,120 \\
\hline Net Income & $-6,686$ & $-9,543$ & $-16,254$ & $-17,586$ & $-23,343$ & $-21,183$ \\
\hline Net transfers & 5,009 & 6,596 & 8,493 & 7,928 & 8,006 & 9,566 \\
\hline o/w EU receipts & 3,902 & 4,239 & 4,523 & 3,885 & 3,826 & 5,223 \\
\hline o/w payment to EU & $-3,031$ & $-3,178$ & $-3,630$ & $-3,912$ & $-4,045$ & $-4,203$ \\
\hline Capital and financial account balance & 16,290 & 14,216 & 44,602 & 48,023 & 16,991 & 17,339 \\
\hline Capital account balance & 995 & 2,105 & 4,771 & 5,989 & 7,421 & 7,716 \\
\hline o/w net EU transfers & 1,012 & 2,290 & 4,660 & 5,828 & 7,535 & 7,835 \\
\hline Financial account balance & 15,295 & 12,111 & 39,831 & 42,034 & 9,571 & 9,623 \\
\hline Foreign direct investment (net) & 7,013 & 10,037 & 17,976 & 12,951 & 7,100 & 7,584 \\
\hline by nonresidents & 10,363 & 19,198 & 22,959 & 16,533 & 8,600 & 8,584 \\
\hline o/w privatization & 31 & 8 & 95 & 100 & 100 & 100 \\
\hline Portfolio investment (net) & 12,600 & $-3,007$ & $-5,032$ & $-2,227$ & 471 & 0 \\
\hline by non-residents & 15,109 & 1,543 & 930 & $-4,435$ & $-1,000$ & 1,000 \\
\hline o/w equities & 1,333 & $-2,134$ & -453 & 584 & -661 & 500 \\
\hline Other investment & $-4,511$ & 5,838 & 28,897 & 31,890 & 2,000 & 2,039 \\
\hline Assets & $-2,782$ & $-3,734$ & $-1,444$ & 6,158 & 1,000 & 1,039 \\
\hline Liabilities & $-1,729$ & 9,572 & 30,341 & 25,732 & 1,000 & 1,000 \\
\hline Financial derivatives & 193 & -757 & $-2,010$ & -580 & 0 & 0 \\
\hline Errors and omissions & $-4,450$ & $-2,536$ & $-11,465$ & $-20,958$ & 0 & 0 \\
\hline Overall balance & 8,135 & 2,480 & 13,037 & $-1,964$ & $-1,043$ & 1,381 \\
\hline \multicolumn{7}{|l|}{ Financing } \\
\hline Reserve assets & $-8,135$ & $-2,480$ & $-13,037$ & 1,964 & 1,043 & $-1,381$ \\
\hline \multicolumn{7}{|l|}{ Memorandum items: } \\
\hline Current plus capital account (percent of GDP) & -0.9 & -2.1 & -3.6 & -4.4 & -2.6 & -2.0 \\
\hline Official reserves & 42,571 & 48,484 & 65,746 & 62,180 & 61,137 & 62,518 \\
\hline in months of imports & 5.2 & 4.7 & 4.9 & 3.7 & 4.6 & 4.5 \\
\hline Ratio of reserves to short-term debt $1 /$ & 101.8 & 97.3 & 103.3 & 81.0 & 67.9 & 66.6 \\
\hline Total external debt (percent of GDP) & 43.7 & 49.6 & 54.9 & 46.0 & 60.2 & 59.5 \\
\hline Total external debt (percent of exports) $2 /$ & 118.0 & 122.9 & 133.9 & 113.8 & 134.2 & 130.5 \\
\hline External debt service (percent of exports) $2 / 3 /$ & 14.7 & 17.0 & 12.9 & 16.1 & 17.7 & 17.5 \\
\hline Gross FDI inflows (percent of GDP) & 3.4 & 5.6 & 5.4 & 3.1 & 2.1 & 2.1 \\
\hline Net FDI inflows (percent of GDP) & 2.3 & 2.9 & 4.2 & 2.5 & 1.8 & 1.8 \\
\hline
\end{tabular}

Sources: National Bank of Poland; and IMF staff estimates.

$1 /$ By remaining maturity.

2/ Exports of goods and services.

3 / Excluding repurchase of debt. 


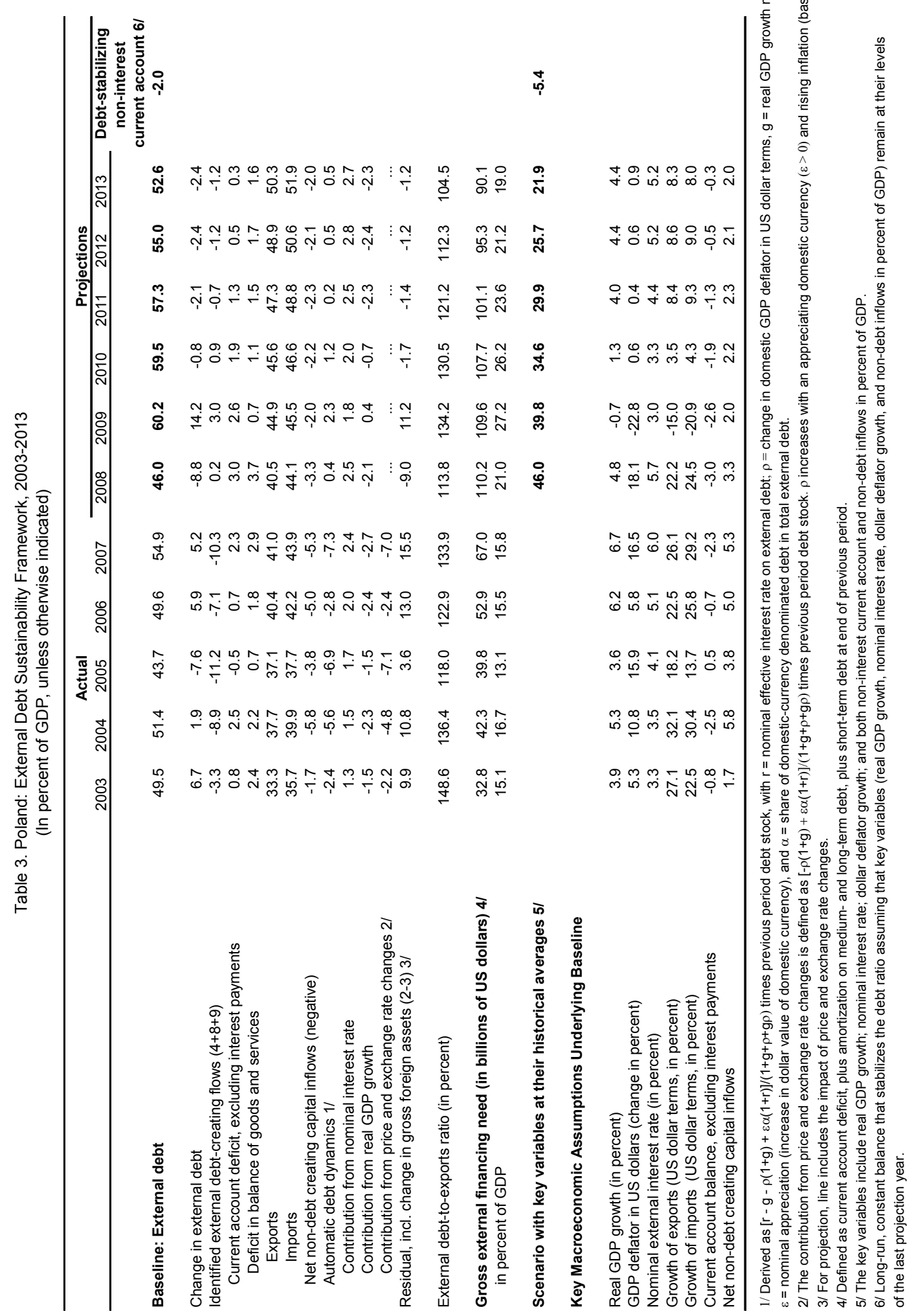


Table 4. Poland: Financial Soundness Indicators, 2002-08 (In percent)

\begin{tabular}{|c|c|c|c|c|c|c|c|}
\hline & 2002 & 2003 & 2004 & 2005 & 2006 & 2007 & $\overline{2008}$ \\
\hline \multicolumn{8}{|l|}{ Capital adequacy } \\
\hline Regulatory capital to risk-weighted assets & 14.2 & 13.8 & 15.4 & 14.5 & 13.2 & 12.1 & 10.8 \\
\hline Regulatory Tier I capital to risk-weighted assets & 14.2 & 13.9 & 15.3 & 14.4 & 12.9 & 11.8 & $\ldots$ \\
\hline NPLs net of provisions to capital & $\ldots$ & 31.1 & 22.5 & 11.9 & 11.6 & 11.4 & 12.6 \\
\hline \multicolumn{8}{|l|}{ Asset composition and quality } \\
\hline NPLs to gross loans & $\ldots$ & 21.2 & 14.9 & 11.0 & 7.4 & 5.2 & 4.4 \\
\hline \multicolumn{8}{|l|}{ Sectoral distribution of loans to total loans } \\
\hline Loan to households & 41.4 & 43.8 & 47.8 & 52.6 & 56.7 & 59.3 & 62.1 \\
\hline Loans to non-financial corporations & 58.6 & 55.9 & 51.8 & 47.1 & 43.0 & 40.4 & 37.5 \\
\hline \multicolumn{8}{|l|}{ Earnings and profitability } \\
\hline Return on average assets (after-tax) & 0.5 & 0.5 & 1.4 & 1.6 & 1.7 & 1.7 & 1.6 \\
\hline Return on average equity (after-tax) & 6.1 & 5.8 & 16.9 & 20.6 & 22.5 & 22.4 & 21.2 \\
\hline Interest margin to gross income & 54.4 & 55.7 & 56.4 & 57.7 & 58.9 & 59.4 & 61.6 \\
\hline Noninterest expenses to gross income & 71.5 & 78.9 & 77.1 & 72.3 & 69.6 & 68.7 & $\ldots$ \\
\hline \multicolumn{8}{|l|}{ Liquidity } \\
\hline Liquid assets to total assets (liquid assets ratio) & 24.1 & 23.1 & 19.4 & 21.2 & 20.1 & 17.1 & $\ldots$ \\
\hline Liquid assets to total short-term liabilities & 27.4 & 32.6 & 27.8 & 29.6 & 28.1 & 24.2 & $\ldots$ \\
\hline \multicolumn{8}{|l|}{ Sensitivity to market risk } \\
\hline Net open positions in FX to capital & 1.1 & 0.4 & 1.6 & 2.0 & -0.1 & 0.6 & $\ldots$ \\
\hline
\end{tabular}

Source: National Bank of Poland. 
Table 5. Poland: General Government Revenues and Expenditures, 2005-10 (In percent of GDP)

\begin{tabular}{lrrrrrr}
\hline & 2005 & 2006 & 2007 & $\begin{array}{r}2008 \\
\text { Prelim. }\end{array}$ & $\begin{array}{r}2009 \\
\text { Proj. } 1 /\end{array}$ & $\begin{array}{r}2010 \\
\text { Proj. }\end{array}$ \\
\hline General government revenue & & & & & & \\
$\quad$ Taxes & 39.1 & 39.8 & 40.0 & 39.2 & 39.3 & 39.8 \\
$\quad$ Direct taxes & 19.8 & 21.2 & 21.6 & 21.5 & 20.7 & 20.7 \\
$\quad$ Indirect taxes & 5.1 & 5.7 & 6.2 & 6.4 & 5.5 & 5.5 \\
$\quad$ Other taxes & 14.6 & 15.3 & 15.2 & 15.0 & 15.0 & 15.1 \\
Social security contributions & 0.1 & 0.1 & 0.1 & 0.1 & 0.2 & 0.2 \\
Other taxes and nontax & 12.0 & 11.9 & 11.9 & 11.1 & 10.7 & 10.9 \\
General government expenditure 2/ & 7.3 & 6.7 & 6.5 & 6.6 & 7.9 & 8.2 \\
Goods and services & 43.0 & 43.7 & 42.0 & 43.1 & 43.6 & 44.0 \\
Transfers and subsidies & 17.6 & 17.6 & 17.5 & 18.0 & 17.7 & 18.0 \\
Interest payments & 19.8 & 20.1 & 18.5 & 18.8 & 19.3 & 19.4 \\
Capital and net lending & 2.5 & 2.6 & 2.3 & 2.2 & 2.5 & 2.7 \\
General government balance 2/ & 3.1 & 3.3 & 3.6 & 4.1 & 4.1 & 3.9 \\
Financing & -3.9 & -3.9 & -2.0 & -3.9 & -4.3 & -4.2 \\
$\quad$ Domestic & 3.9 & 3.9 & 2.0 & 3.9 & 4.3 & 4.2 \\
External & 2.3 & 3.2 & 1.3 & 3.2 & 3.6 & 3.5 \\
Privatization & 1.2 & 0.7 & 0.6 & 0.6 & 0.5 & 0.5 \\
Memorandum items: & 0.3 & 0.0 & 0.1 & 0.2 & 0.2 & 0.1 \\
Primary balance & & & & & & \\
State balance & -1.3 & -1.3 & 0.3 & -1.7 & -1.8 & -1.5 \\
Rest of government balance & -4.2 & -3.8 & -2.8 & -4.0 & -3.1 & -3.5 \\
Public debt & 0.3 & -0.1 & 0.8 & 0.0 & -1.2 & -0.7 \\
\hline
\end{tabular}

Sources: Polish authorities; and IMF staff estimates and projections.

$1 / 2009$ projection includes the authorities' planned measures of 1.8 percent of GDP (0.4 percent of GDP higher dividend payment, 1.2 percent of GDP in general expenditure cut and 0.2 percent of GDP in underexecution of road spending).

2/ Second-pillar pension funds (OFEs) classified outside government. 


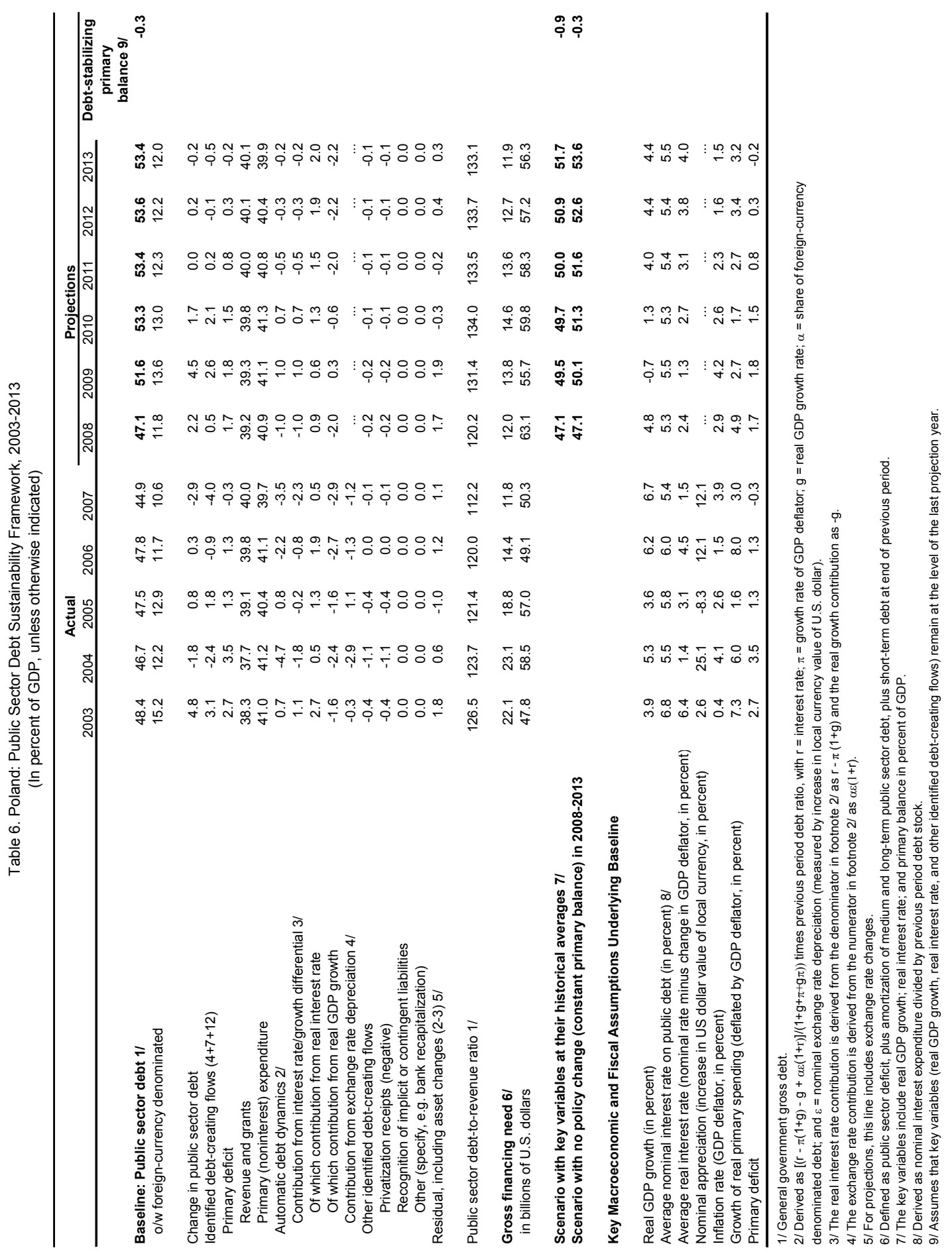


Table 7. Poland: External Financing Requirements and Sources, 2009 (In million of U.S. dollars)

\begin{tabular}{|c|c|c|}
\hline & $\begin{array}{c}\text { Full-rollover } \\
\text { Baseline Scenario }\end{array}$ & Adverse Scenario \\
\hline GROSS FINANCING REQUIREMENTS & 105,817 & 105,817 \\
\hline Current account deficit & 18,034 & 18,034 \\
\hline Medium and long-term debt amortization $1 /$ & 20,839 & 20,839 \\
\hline Public sector & 4,411 & 4,411 \\
\hline Banks & 3,903 & 3,903 \\
\hline Non-bank Corporates & 12,525 & 12,525 \\
\hline Short-term debt amortization $1 /$ & 66,944 & 66,944 \\
\hline Public sector & 618 & 618 \\
\hline Banks (inc. s.t. deposits) & 28,484 & 28,484 \\
\hline Non-bank Corporates & 37,842 & 37,842 \\
\hline o/w trade credit & 31,030 & 31,030 \\
\hline SOURCES OF FINANCING & 104,889 & 84,591 \\
\hline Foreign direct investment (net) & 7,100 & 6,035 \\
\hline o/w inward (net) & 8,600 & 7,310 \\
\hline Portfolio (equity, net) & 471 & -619 \\
\hline by nonresidents & -661 & $-1,751$ \\
\hline Medium and long-term debt rollovers & 20,839 & 17,112 \\
\hline Public sector & 4,411 & 3,970 \\
\hline Banks & 3,903 & 3,122 \\
\hline Non-bank Corporates & 12,525 & 10,020 \\
\hline Short-term rollovers & 66,944 & 54,528 \\
\hline Public sector & 618 & 618 \\
\hline Banks & 28,484 & 23,636 \\
\hline Foreign subsidiaries to parent banks & 8,491 & 7,642 \\
\hline Other & 19,993 & 15,994 \\
\hline Non-bank Corporates & 37,842 & 30,274 \\
\hline Other Investment & 2,000 & -500 \\
\hline EU transfers (Capital) & 7,535 & 7,535 \\
\hline BUFFERS & 929.1 & $3,878.6$ \\
\hline Use of official reserves $2 /$ & 929 & 929 \\
\hline Private liquid foreign assets & 0 & 2,950 \\
\hline FINANCING GAP & 0 & 17,348 \\
\hline In billions of SDR & $\ldots$ & 11,603 \\
\hline In percent of quota & $\cdots$ & $848 \%$ \\
\hline \multicolumn{3}{|l|}{ Memorandum items } \\
\hline Net International Reserves (if used to fill financing gap) & 58,427 & 41,079 \\
\hline months of imports & 3.8 & 2.7 \\
\hline
\end{tabular}


Table 8. Poland: Assumptions underlying Adverse Financing Scenario (in percent, unless otherwise specified)

FDI (decline with respect to the baseline)

Equity portfolio (outflow of non-residents portfolio holdings)

Debt portfolio (rollover of debt liabilities falling due)

MLT debt borrowing

Sovereign

Banks

Corporates

ST debt borrowing

Sovereign

Banks

Foreign subsidiaries

Other

Corporates

Other investment (outflows with respect to the baseline, in USD billion) 
Table 9. Poland: Monetary Accounts, 2004-09

\begin{tabular}{|c|c|c|c|c|c|c|}
\hline & 2004 & 2005 & 2006 & 2007 & 2008 & Jan-09 \\
\hline \multicolumn{7}{|c|}{ (In billions of zloty) } \\
\hline \multicolumn{7}{|l|}{ Monetary Survey } \\
\hline Net foreign assets & 148 & 180 & 167 & 121 & 64 & 75 \\
\hline Net domestic assets & 348 & 368 & 446 & 545 & 764 & 776 \\
\hline Claims on Central Government (Net) & 69 & 65 & 73 & 62 & 111 & 105 \\
\hline Claims on Other General Govt. & 18 & 19 & 20 & 18 & 21 & 20 \\
\hline Claims on Other Resident Sectors & 260 & 285 & 353 & 464 & 633 & 650 \\
\hline Other items, net & -13 & -8 & 2 & 18 & -21 & -40 \\
\hline Broad money & 386 & 435 & 500 & 565 & 673 & 676 \\
\hline Money market funds & 0 & 0 & 0 & 0 & 1 & 1 \\
\hline Bonds & 6 & 10 & 15 & 13 & 13 & 12 \\
\hline Capital accounts & 91 & 96 & 99 & 106 & 121 & $\cdots$ \\
\hline \multicolumn{7}{|l|}{ Accounts of the NBP } \\
\hline Net foreign assets & 114 & 138 & 138 & 140 & 177 & 194 \\
\hline Net domestic assets & -24 & -47 & -40 & -39 & -21 & -17 \\
\hline Net claims on government & -14 & -16 & -17 & -26 & -21 & -15 \\
\hline Claims on Other General Govt. & 0 & 0 & 0 & 0 & 0 & 0 \\
\hline Claims on Other Resident Sectors & 0 & 0 & 0 & 0 & 0 & 0 \\
\hline Net claims on banks & -11 & -30 & -24 & -13 & 1 & -3 \\
\hline Other items, net & -17 & -16 & -5 & 9 & -18 & -39 \\
\hline Base money & 70 & 72 & 89 & 107 & 134 & 132 \\
\hline NBP Capital & 3 & 3 & 3 & 4 & 5 & $\ldots$ \\
\hline \multicolumn{7}{|l|}{ Deposit Money Banks } \\
\hline Net foreign assets & 34 & 42 & 29 & -19 & -113 & -118 \\
\hline Net domestic assets & 394 & 432 & 510 & 613 & 840 & 844 \\
\hline Domestic credit & 361 & 384 & 462 & 571 & 786 & 790 \\
\hline Net claims on government & 83 & 81 & 90 & 88 & 132 & 120 \\
\hline Claims on Other General Govt. & 18 & 19 & 20 & 18 & 21 & 20 \\
\hline Claims on Other Resident Sectors & 260 & 284 & 353 & 464 & 633 & 650 \\
\hline Banks' reserves & 18 & 14 & 18 & 26 & 36 & 36 \\
\hline Other items, net & 4 & 8 & 7 & 8 & -4 & -2 \\
\hline Deposit & 334 & 377 & 429 & 484 & 575 & 580 \\
\hline Liabilities to the NBP & 3 & 2 & 5 & 3 & 18 & 13 \\
\hline Banks' capital & 88 & 92 & 96 & 102 & 117 & 118 \\
\hline Money market funds & 0 & 0 & 0 & 0 & 1 & 1 \\
\hline \multirow[t]{2}{*}{ Bonds } & 6 & 10 & 15 & 13 & 13 & 12 \\
\hline & \multicolumn{6}{|c|}{ (Percentage change from end of previous year) } \\
\hline Base money & 5.5 & 2.8 & 23.9 & 19.8 & 25.1 & 24.6 \\
\hline Broad money & 7.9 & 12.8 & 14.8 & 13.0 & 19.1 & 18.1 \\
\hline Net domestic assets & 7.3 & 5.9 & 21.1 & 22.2 & 40.4 & 39.9 \\
\hline Net foreign assets & 8.9 & 21.7 & -7.5 & -27.5 & -46.9 & -39.8 \\
\hline Net claim on government & -7.2 & -6.5 & 12.8 & -14.9 & 79.1 & 78.6 \\
\hline Credit to other resident sectors & 10.0 & 9.3 & 24.0 & 31.5 & 36.4 & 36.3 \\
\hline \multirow[t]{2}{*}{ Deposit growth } & 8.3 & 12.8 & 13.8 & 12.7 & 19.0 & 17.6 \\
\hline & \multicolumn{5}{|c|}{ (In percent of GDP) } & \\
\hline Broad money & 41.7 & 44.3 & 47.1 & 48.0 & 53.1 & $\ldots$ \\
\hline Domestic credit & 37.6 & 37.4 & 42.0 & 46.3 & 60.4 & $\ldots$ \\
\hline Private sector credit & 28.1 & 28.9 & 33.3 & 39.5 & 50.0 & ... \\
\hline Velocity & 2.4 & 2.3 & 2.1 & 2.1 & 1.9 & $\cdots$ \\
\hline Money multiplier & 5.5 & 6.0 & 5.6 & 5.3 & 5.0 & $\ldots$ \\
\hline
\end{tabular}

Sources: IFS and staff estimates and projections. 
Dear Mr. Strauss-Kahn,

I would like the Fund to approve for Poland a Flexible Credit Line (FCL) arrangement in the amount of SDR 13.69 billion (1000 percent of quota) covering a period of 12 months. Should the arrangement be approved, it is Poland's intention to treat it as precautionary.

Poland has made important strides in recent years, with robust and well-balanced growth underpinned by a very strong institutional policy framework, a sustained track record of implementing sustainable fiscal and monetary policies, and important structural reforms. As a result, economic fundamentals have improved markedly, and our resilience to economic shocks has been reinforced. Poland's recent policy response demonstrates our continued commitment to macroeconomic stability. Specifically, it aims to help weather the impact on the Polish economy of a prolonged global downturn and regional spillovers:

- We remain committed to the budgetary policy framework of the EU's Stability and Growth Pact. In addition, we will continue strengthening our medium-term fiscal framework toward maintaining our sustainable path for public debt.

- As elaborated in the attached letter from the governor of the National Bank of Poland, Mr. Sławomir Skrzypek, Poland's disciplined and transparent inflationtargeting framework - which over the past decade has helped build credibility and anchor long-run inflation expectations - will continue to underpin Poland's monetary policy strategy. Timely policy reaction to renewed price pressures last year is helping to reduce inflation to its tolerance range. In the current cyclical juncture, consistent with euro interest rate cuts, the Central Bank has embarked on a loosening cycle, reducing policy rates by 225 basis points since November, and stands ready to cut rates further if downside risks to the economy materialize, while monitoring the exchange rate pass through and potential balance-sheet effects.

- Poland's banking system is profitable and well capitalized. Still, in this time of uncertainty, we have been vigilant and have been actively utilizing available tools to safeguard financial sector stability - in line with past FSAP recommendations. In this regard, we have stepped up our financial sector surveillance work, including by higher frequency of stress tests and data reporting. We have also engaged with the Polish banks and addressed their 
needs by broadening our tools to provide liquidity both in Zloty and in foreign currency. However, as the global crisis deepens, credit risks are rising. Under an adverse scenario, our strengthened an unified supervisory agency as well as our institutional framework for financial stability will provide us with adequate legal and institutional instruments to address any potential crisis management and resolution needs.

Poland has strong policy framework and sound fundamentals, but has nevertheless been negatively affected by external shocks that are beyond our control. These strong policies and fundamentals have allowed us to maintain unimpeded access to international markets. Still, given potential downside risks from regional spillovers, an FCL on a precautionary basis will help bolster investor's confidence by providing assurance to the markets that Poland has the potential reserves needed to cushion a deterioration of the external environment in the event that downside risks materialize.

In sum, as recognized by the Executive Board in the most recent Article IV consultation, Poland's economic success has been built upon a bedrock of strong policies and institutions, as well as a willingness to respond promptly and effectively to new challenges as they arise. We will continue to react as needed to deal with any future shocks that may emerge.

Sincerely yours,

$\backslash \mathbf{s} \backslash$

Minister of Finance

Jan Vincent-Rostowski 
Warsaw, April 23, 2009

Mr. Dominique Strauss-Kahn,

Managing Director

International Monetary Fund

Dear Mr. Strauss-Kahn:

I am writing in support of Poland's Minister of Finance, Mr. Jan Vincent-Rostowski's request for a Flexible Credit Line (FCL) arrangement in the amount of SDR 13.69 billion (1000 percent of quota) covering a period of 12 months.

Poland has made important strides in recent years, with robust and well-balanced growth underpinned by a very strong institutional policy framework, a sustained track record of implementing fiscal and monetary policies, and important structural reforms.

Poland's economic fundamental have improved markedly over last years. The recent policy response demonstrates a continued commitment to macroeconomic stability. This stability has been enhanced by the transparent and credible monetary policy based on the direct inflation targeting regime. Timely policy response to renewed price pressures last year is helping to cut inflation to its tolerance range. In the current cyclical juncture, consistent with euro interest rate cuts, the Monetary Policy Council has embarked on a loosening cycle, reducing policy rates by 225 basis points since November, and stands ready to cut rates further if downside risks to the economy materialize.

While Poland's banking system is sound and well capitalized, it has nevertheless been negatively affected by external shocks. We have been vigilant and have been actively utilizing available tools to safeguard financial sector stability. In this regard, we have intensified our financial sector surveillance work, including by higher frequency of stress tests an data reporting. We have engaged with the Polish banks and addressed their needs by broadening our tools to provide liquidity both in Zloty and in foreign currency. However, as the global crisis deepens, credit risks are rising.

I am confident that FCL arrangement as a precautionary measure will be a strong tool in strengthening market confidence in Poland's capacity to cushion a potential deterioration of the external environment.

I would like to assure you of the NBP's full cooperation with the International Monetary Fund and the support of the Polish Minister of Finance in his efforts to build a sustainable economy.

Yours sincerely,

$\backslash \mathbf{s} \backslash$

President of National Bank of Poland

Sławomir Skrzypek 


\title{
Republic of Poland-Assessment of the Impact of the Proposed Flexible Credit Line Arrangement on the Fund's Finances and Liquidity Position
}

\author{
Prepared by the Finance and Strategy, Policy and Review Departments
}

(In consultation with other Departments)

Approved by Andrew Tweedie and Philip Gerson

April 28, 2009

\section{This note assesses the impact of the proposed Flexible Credit Line (FCL)} arrangement for Poland on the Fund's finances and liquidity position, in accordance with the policy on the FCL. ${ }^{6}$ The proposed arrangement would cover a 12-month period, and be in an amount of SDR 13.7 billion (1,000 percent of quota). The full amount of access proposed would be available throughout the arrangement period, in one or multiple purchases. $^{7}$ The authorities intend to treat the arrangement as precautionary.

\section{BACKGROUND}

\section{Poland had several Fund arrangements in the 1990s until it extinguished its} remaining outstanding credit in 1995 (Table 1). In order to facilitate its transition, Poland had three Stand-By Arrangements (SBAs) and one arrangement using a blend of the Extended Fund Facility (EFF) and Compensatory Financing Facility (CFF) from 1990 to 1994. Access under the latter arrangement approved in 1991 was the largest at SDR 1.2 billion. The two subsequent SBAs brought Fund exposure to its peak in 1994 of just below SDR 1 billion (Figure 1), reflecting the fact that Poland had not drawn the full amounts available under any of its Fund arrangements. Poland extinguished all outstanding obligations to the Fund through two advance repurchases in 1995.

\footnotetext{
${ }^{6}$ See GRA Lending Toolkit and Conditionality—Reform Proposals (3/13/09), and GRA Lending Toolkit and Conditionality—Reform Proposals (3/24/09).

${ }^{7}$ If the full amount is not drawn in the first six months of the arrangement, subsequent purchases are subject to a review of Poland's continued qualification for the FCL arrangement.
} 
Table 1. Poland: IMF Financial Arrangements, 1990-1995

(In millions of SDR)

\begin{tabular}{|c|c|c|c|c|c|c|c|c|}
\hline Year & $\begin{array}{c}\text { Type of } \\
\text { Arrangement }\end{array}$ & $\begin{array}{c}\text { Date of } \\
\text { Arrangement }\end{array}$ & $\begin{array}{l}\text { Date of } \\
\text { Expiration or } \\
\text { Cancellation }\end{array}$ & $\begin{array}{c}\text { Amount of } \\
\text { New } \\
\text { Arrangement }\end{array}$ & $\begin{array}{l}\text { Amount } \\
\text { Drawn }\end{array}$ & Purchases & Repurchases & $\begin{array}{l}\text { Fund Exposure } \\
\qquad 1 /\end{array}$ \\
\hline 1990 & SBA & 5-Feb-90 & 4-Mar-91 & 545.0 & 357.5 & 357.5 & 0.0 & 357.5 \\
\hline 1991 & EFF/CFF & 18-Apr-91 & 8-Mar-93 & $1,224.0$ & 76.5 & $239.1 \quad 2 /$ & 0.0 & 596.6 \\
\hline 1992 & & & & & & 0.0 & 0.0 & 596.6 \\
\hline 1993 & SBA & 8-Mar-93 & 8-Apr-94 & 476.0 & 357.0 & 0.0 & 98.9 & 497.7 \\
\hline 1994 & SBA & 5-Aug-94 & 4-Mar-96 & 333.3 & 283.3 & 640.3 & 219.4 & 918.6 \\
\hline 1995 & & & & & & 0.0 & 918.6 & 0.0 \\
\hline
\end{tabular}

Source: Finance Department.

$1 /$ As of end-December.

2/ Includes a purchase of SDR 162.6 million under the Compensatory Financing Facility.

Figure 1. Poland: IMF Credit Outstanding, 1990-1995

(In millions of SDRs)

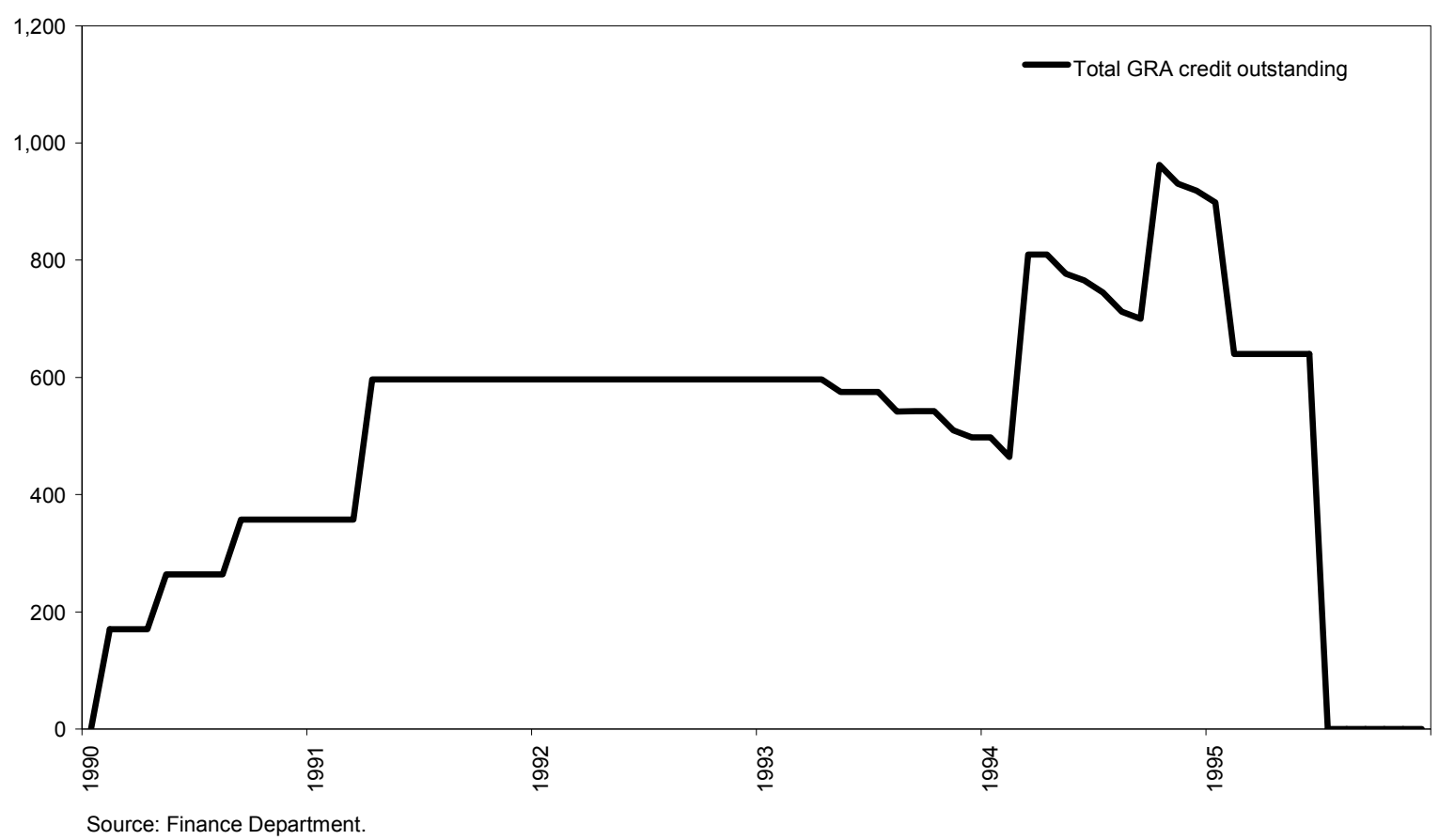

3. Total external debt is significant but sustainable (Table 2). ${ }^{8}$ External debt has been stable around 50 percent of GDP in recent years, and is projected to rise to about 60 percent of GDP in 2009 owing mainly to the depreciation of the zloty. Short-term debt on a residual

\footnotetext{
${ }^{8}$ A more detailed description and analysis of external and public debt is provided in the staff report.
} 
maturity basis accounts for over one-quarter of this total. Public external debt is projected to increase to about 17 percent of GDP in 2009. Gross public debt has stabilized at about 45 percent of GDP in recent years, and while some increase is projected in the near-term, sustainability analysis shows debt remaining manageable under a range of scenarios, with no significant contingent liabilities incurred thus far during the crisis.

Table 2. Poland: Total External Debt, 2005-2009

(In millions of SDR)

\begin{tabular}{lrrrrr}
\hline & 2005 & 2006 & 2007 & 2008 & 2009 1/ \\
\hline & \multicolumn{5}{c}{ (In Billions of US Dollars) } \\
\cline { 2 - 6 } Total External Debt & 133 & 170 & 233 & 242 & 243 \\
$\quad$ Private & 72 & 101 & 146 & 172 & 173 \\
Public & 61 & 69 & 87 & 70 & 69 \\
& \multicolumn{7}{c}{ (In Percent of GDP) } \\
Total External Debt & 43.7 & 49.6 & 54.9 & 46.0 & 60.2 \\
$\quad$ Private & 23.7 & 29.5 & 34.3 & 32.7 & 43.0 \\
$\quad$ Public & 20.0 & 20.2 & 20.6 & 13.3 & 17.2 \\
\hline
\end{tabular}

Source: Polish authorities and IMF staff estimates.

1/ Projected.

\section{IMPACT ON THE FUND'S FinANCES AND LIQUIDITY POSITION}

4. The substantial access under the proposed arrangement could add significantly to the Fund's credit exposure. In terms of SDRs, the proposed FCL arrangement would be more than ten times Poland's largest arrangement to date. If the full amount available under the FCL arrangement - which the authorities intend to treat as precautionary - were drawn, Poland's outstanding use of GRA resources would reach SDR 13.7 billion, an individual country exposure which has previously been exceeded in only four cases, including augmentations.

\section{If the full amount available under the proposed FCL arrangement were purchased in 2009:}

- $\quad$ Poland's external debt position would increase somewhat, with Fund credit representing a modest part of this debt: total external debt would rise to about 65 percent of GDP initially, and public external debt would rise to about 22 percent of GDP, with Fund credit at about 5 percent of GDP (Table 3). At its peak in 2009, Poland's outstanding use of GRA resources would account for less than one-tenth of total external debt, about one-quarter of public external debt, and also about onequarter of reserves. 
- $\quad$ External debt service would increase over the medium-term, but would remain manageable. Poland's projected debt service to the Fund would peak in 2013 at about SDR 7 billion, or 2.2 percent of GDP. ${ }^{9}$ In terms of exports of goods and services, debt service to the Fund would peak at about 4.4 percent, accounting for about 70 percent of total public external debt service.

Table 3. Poland: Capacity to Repay Indicators 1/

\begin{tabular}{|c|c|c|c|c|c|c|c|}
\hline & 2008 & 2009 & 2010 & 2011 & 2012 & 2013 & 2014 \\
\hline \multicolumn{8}{|l|}{ Exposure and Repayments (In SDR millions) } \\
\hline GRA credit to Poland & -- & $13,690.0$ & $13,690.0$ & $13,690.0$ & $10,267.5$ & $3,422.5$ & - \\
\hline (In percent of quota) & -- & $(1,000.0)$ & $(1,000.0)$ & $(1,000.0)$ & $(750.0)$ & $(250.0)$ & -- \\
\hline Charges due on GRA credit 2/ & -- & 287.1 & 402.5 & 402.5 & 387.9 & 196.1 & 20.2 \\
\hline Debt service due on GRA credit 2/ & -- & 287.1 & 402.5 & 402.5 & $3,810.4$ & $7,041.1$ & $3,442.7$ \\
\hline \multicolumn{8}{|l|}{ Debt and Debt Service Ratios 3/ } \\
\hline \multicolumn{8}{|l|}{ In percent of GDP } \\
\hline Total external debt & 46.0 & 65.3 & 64.4 & 62.1 & 58.3 & 53.6 & 50.3 \\
\hline Public external debt & 13.3 & 22.2 & 21.8 & 20.9 & 18.8 & 15.7 & 13.8 \\
\hline GRA credit to Poland & -- & 5.1 & 5.0 & 4.8 & 3.4 & 1.1 & -- \\
\hline Total external debt service & 6.5 & 8.0 & 8.1 & 8.4 & 9.6 & 10.1 & 8.6 \\
\hline Public external debt service & 0.9 & 1.1 & 1.1 & 1.2 & 2.3 & 3.2 & 2.0 \\
\hline Debt service due on GRA credit & -- & 0.1 & 0.1 & 0.1 & 1.3 & 2.2 & 1.0 \\
\hline \multicolumn{8}{|l|}{ In percent of Gross International Reserves } \\
\hline Total external debt & 389.3 & 316.3 & 307.9 & 295.1 & 283.4 & 277.6 & 263.2 \\
\hline Public external debt & 112.8 & 107.7 & 104.3 & 99.4 & 91.1 & 81.0 & 72.5 \\
\hline GRA credit to Poland & - & 24.6 & 23.9 & 22.7 & 16.6 & 5.6 & - \\
\hline \multicolumn{8}{|l|}{ In percent of Exports of Goods and Services } \\
\hline Total external debt service & 16.1 & 17.9 & 17.8 & 17.7 & 19.6 & 20.2 & 17.0 \\
\hline Public external debt service & 2.3 & 2.4 & 2.5 & 2.4 & 4.7 & 6.4 & 3.9 \\
\hline Debt service due on GRA credit & -- & 0.2 & 0.3 & 0.3 & 2.6 & 4.4 & 2.0 \\
\hline \multicolumn{8}{|l|}{ In percent of Total External Debt } \\
\hline GRA credit to Poland & -- & 7.8 & 7.7 & 7.7 & 5.9 & 2.0 & -- \\
\hline \multicolumn{8}{|l|}{ In percent of Public External Debt } \\
\hline GRA credit to Poland & -- & 22.9 & 22.9 & 22.9 & 18.2 & 6.9 & -- \\
\hline U. S. dollars per SDR (period average) & 1.50 & 1.50 & 1.50 & 1.50 & 1.50 & 1.50 & 1.50 \\
\hline U. S. dollars per SDR (end of period) & 1.50 & 1.50 & 1.50 & 1.50 & 1.50 & 1.50 & 1.50 \\
\hline
\end{tabular}

Sources: Polish authorities, Finance Department, World Economic Outlook, and IMF staff estimates.

1/ Assumes full drawings under the FCL upon approval. The Polish authorities have expressed their intention to treat the arrangement as precautionary, as balance of payments pressures have not materialized.

2/ Based on the rate of charge as of April 22, 2009. Includes surcharges under the system currently in force and service charges.

3/ Staff projections for external debt, GDP, gross international reserves, and exports of goods and services, as used in the staff report that requests the proposed FCL, adjusted for the impact of the assumed FCL drawing.

\footnotetext{
${ }^{9}$ The figures on debt service used in this report are calculated assuming that full amount available under the arrangement is purchased upon approval of the arrangement, and that all repurchases are made as scheduled.
} 
6. Reflecting the high access under the arrangement, the impact on the Fund's liquidity, and on its potential credit risk exposure, would be substantial:

- The proposed arrangement would reduce Fund liquidity by the full amount of available access (Table 4). Approval of the proposed arrangement would reduce the one-year forward commitment capacity (FCC) by SDR 13.7 billion. In addition to quota resources included in the FCC, the Fund also has supplementary resources under the borrowing agreement with Japan.

- If the resources available under the FCL arrangement were fully drawn, GRA credit to Poland as a share of total GRA credit would be about 40 percent. As a result, the concentration of Fund credit among the top five users of Fund resources would increase to about 90 percent.

- $\quad$ Potential GRA exposure to Poland would be large in relation to the current level of the Fund's precautionary balances. If the resources available under the arrangement were fully drawn, Fund credit to Poland would be equivalent to almost twice the Fund's current precautionary balances.

Table 4. FCL Arrangement for Poland-Impact on GRA Finances

(In SDR millions, unless otherwise indicated)

\begin{tabular}{lr}
\hline & As of 4/23/2009 \\
\hline Liquidity measures & 66,705 \\
$\quad$ Current one-year Forward Commitment Capacity (FCC) 1/ & 67,325 \\
Japan borrowing agreement, available resources & 13,690 \\
& \\
Reduction in FCC on approval of FCL & 40.1 \\
Prudential measures, assuming full FCL drawing & 197.3 \\
Fund credit to Poland & 86.3 \\
$\quad$ In percent of total GRA credit outstanding 2/ & 90.1 \\
In percent of current precautionary balances & \\
Fund credit outstanding to five largest debtors & 6,939 \\
$\quad$ In percent of total GRA credit outstanding, before approval & 45,218 \\
$\quad$ In percent of total GRA credit outstanding, upon approval of the FCL $2 /$ & 2.8 \\
\hline
\end{tabular}

Sources: Finance Department.

1/ The FCC measures the Fund's capacity to make new credit commitments over the next 12 months.

2/ Based on current Fund credit outstanding plus full drawings under the proposed FCL. 


\begin{abstract}
ASSESSMENT
7. The proposed arrangement would have a large but manageable impact on Fund liquidity. Nonetheless, the Fund's liquidity has declined rapidly in recent weeks, and is likely to continue decline as the Board considers requests for arrangements that have already been announced or are in the pipeline. This underscores the need for continued close monitoring of liquidity, and to expedite the efforts to bring new borrowing agreements into effect to supplement the Fund's resources.

8. Poland intends to treat the FCL arrangement as precautionary, but if it did prove necessary to draw, the Fund's credit exposure to Poland would be large. Poland's overall external and public debt dynamics are expected to remain sustainable including should adverse shocks materialize such that a drawing became necessary. Poland's very strong policy record, and the very strong legislative and institution policy framework, provide assurances about the future course of policies, such that Poland's capacity to repay is projected to remain strong. Nonetheless, the scale of the Fund's potential exposure to Poland - in conjunction with the recent commitments to other members and the prospects for further credit expansion in the pipeline - underscores the need to strengthen the Fund's precautionary balances.
\end{abstract}


Press Release No. 09/153

International Monetary Fund

FOR IMMEDIATE RELEASE

Washington, D.C. 20431 USA

May 6, 2009

\section{IMF Executive Board Approves US\$20.58 Billion Arrangement for Poland Under the Flexible Credit Line}

The Executive Board of the International Monetary Fund (IMF) today approved a one-year SDR 13.69 billion (about US\$20.58 billion; 1,000 percent of quota) arrangement for Poland under the Flexible Credit Line (FCL). The Polish authorities intend to treat the arrangement as precautionary, which means that they do not intend to draw from the FCL.

The arrangement for Poland is the second commitment, after Mexico, under the IMF's FCL, which was created in the context of a major overhaul of the Fund's lending framework on March 24, 2009 (see Press Release No. 09/85 and Public Information Notice 09/40). The FCL is particularly useful for crisis prevention purposes as it provides the flexibility to draw on the credit line at any time. Disbursements are neither phased nor conditioned on compliance with policy targets as in traditional IMF-supported programs. This flexible access is justified by the very strong track records of countries that qualify for the FCL, which gives confidence that their economic policies will remain strong.

Following the Executive Board's discussion on Poland, Mr. John Lipsky, First Deputy Managing Director and Acting Chair, made the following statement:

"Poland's economic growth has been very strong and well-balanced in recent years. Private consumption growth has been robust, the external position is sustainable, and the banking sector is well-capitalized. The avoidance of acute imbalances during the boom years reflects a very strong and timely policy implementation. A long-standing and effective inflationtargeting regime and a freely-floating exchange rate have helped build confidence in monetary institutions and anchor inflation expectations. The authorities' EU commitments and their euro adoption target have provided a strong fiscal anchor. Banking supervision has been fully compliant with EU laws and directives. Its institutional framework has been buttressed by the unification of financial supervision and the creation of the Financial Stability Committee. 
"Despite very strong fundamentals, Poland's economy is now facing the risk of spillovers from the global crisis through both the real and financial sector channels. Exports have contracted and economic activity has slowed in early 2009, reflecting a deep recession in its main trading partners. A sharp slowdown in credit growth is underway as banks have begun to tighten credit criteria. Nonetheless, Poland has maintained access to international capital markets.

"The authorities have responded in a timely and effective manner to the global downturn. They have embarked on a monetary loosening cycle, and stand ready to cut rates further if downside risks to the economy materialize. Financial sector stability has been safeguarded, through liquidity provision and intensified surveillance. Despite the slowdown in growth, the authorities remain committed to the 2009 state budget, primarily by cutting expenditure at the state level. They reaffirmed their full commitment to strengthen the medium-term fiscal framework to maintain a sustainable path for public debt.

"The Executive Board considered that a precautionary arrangement under the Flexible Credit Line (FCL) for Poland would play an important role in supporting the authorities' policy response, boosting market confidence, and placing Poland in a better position to manage adverse developments. The FCL arrangement for Poland will also have a positive regional impact," Mr. Lipsky said .

Poland joined the IMF on June 12, 1986; its quota is SDR 1.36 billion (about US\$2.06 billion). The country's latest use of Fund resources was under a Stand-By Arrangement that expired on March 4, 1996. 


\section{Statement by Katarzyna Zajdel-Kurowska, Alternate Executive Director for the Republic of Poland and Pawel Gasiorowski, Advisor to the Executive Director \\ May 6, 2009}

We would like to thank staff for the report that supports Poland's request for an arrangement under the Flexible Credit Line (FCL). The Polish authorities are requesting a one year arrangement with access of 1,000 percent of quota, which they intend to consider as precautionary.

From the beginning of the application process, the authorities were fully convinced that access to the FCL would help the Polish economy to withstand the current global turbulence by alleviating some of the exaggerated concerns, and would help to sustain the positive market sentiment towards Poland. This was reflected in a very positive reaction of the market after the official announcement of the request. Our authorities also believe that the approval of the FCL for Poland, by strengthening the stability of the Polish economy, would have a positive spillover effect in the region.

\section{Macroeconomic situation}

Over the last decade, Poland has made impressive progress towards a modern, market-based economy with robust and balanced growth. The structural reforms have helped to strengthen fundamentals of the economy and reduce the unemployment rate. In 2008, economic growth was still strong, reaching 4.9 percent. Despite the adverse impact of the continued global slowdown on the real economy, the Polish authorities expect GDP growth to remain in positive territory in 2009 .

\section{Fiscal policy}

A strong economic upturn after the EU entry and structural reforms have positively impacted the fiscal stance. At the end of 2007, the general government deficit (including the cost of pension reform of around 2 percent of GDP) was reduced to 2 percent of GDP from 3.8 percent in 2006 and 4.3 percent in 2005. As a result, in July 2008 the Excessive Deficit Procedure against Poland was abrogated. Moreover, an ambitious program of forwardlooking structural reforms was introduced in early 2008 with the aim to reduce the fiscal burden and improve labor supply mobilization. However, the significant slowdown of the global economy in the second half of 2008 reduced the budgetary revenues and resulted in a higher fiscal deficit in 2008.

The authorities remain fully committed to the budgetary policy framework of the EU's Stability and Growth Pact and continue to strengthen the medium-term fiscal framework to maintain a sustainable path for public debt. The introduction of the medium-term debt management strategy, aimed at the minimization of refinancing risk and smoothing the costs of debt service, also helped to change the structure of public debt. External public debt represents less than 25 percent of total public debt (down from 100 percent in the mid1990s), with an average duration of 6 years and an average maturity of over 8 years. 


\section{Monetary policy}

The transparent inflation targeting framework and the floating exchange rate regime have helped to absorb external shocks. Timely policy reaction to contain second-round effects from last year's commodity price shock helped to reduce inflation back to the National Bank of Poland's (NBP) tolerance range. At the current cyclical juncture, the NBP has embarked on a loosening cycle, reducing the policy rate by 225 basis points since last November, and it stands ready to cut rates further if downside risks to the economy materialize, while monitoring the exchange rate pass through and potential balance sheet effects.

\section{Euro adoption}

The government's plans to adopt the euro are still a top priority. In the fall of 2008, the roadmap for euro adoption was approved by the government after consultations with the monetary authorities. However, the continued severe tensions in the financial markets that have caused much higher volatility of the Polish zloty forced the authorities to suspend ERM2 entry, originally scheduled for the first half of 2009, until more stability has returned to financial markets.

\section{Financial sector}

The domestic banking sector remains strong and stable. In 2008 the net profits of the Polish banking sector (which constitutes almost three quarters of the financial sector assets) reached a record high level of PLN 13.9 bn (US $\$ 4.7$ bn). However, the last quarter of 2008 brought a worsening of profits due to rising costs related to credit risk, increasing funding costs, and increased volatility of asset prices in the financial markets. Despite the less positive outcome in the last quarter of 2008 and a more subdued outlook for 2009, the developments in the financial markets do not pose a direct threat to the stability of the banking system.

The capital adequacy ratio is above the statutory level for all banks operating in Poland. Nevertheless, a majority of banks have revealed their willingness to retain the 2008 profits for an increase of capital, similar to the decision on the 2007 profits.

The banking sector still remains over liquid en bloc. Despite the fall of excess liquidity in the Polish interbank market in Q4 2008, most subsidiaries of foreign banks in Poland were able to obtain funding from their foreign parent banks.

To ensure proper and effective coordination of actions relating to the stability of the national financial system, a Financial Stability Committee (KSF) has been set up. The KSF consists of the Minister of Finance, the Governor of the National Bank of Poland and the Chairman of the Polish Financial Supervision Authority. Under the KSF auspices, a National Contingency Plan was adopted to facilitate the management of a potential crisis situation affecting the domestic financial market. The plan establishes more detailed procedures of cooperation among the institutions. 
Responding to the global turbulence and its spillover to the Polish economy, the authorities introduced a number of further measures aimed at supporting the financial market.

In order to mitigate the problem of FX risk hedging by Polish banks, the NBP offers foreignexchange swaps and three-month repos to banks. Additionally, starting in May 2009, the instruments will be modified, extending the maturities of repo operations to 6 months, broadening the range of eligible collateral for repo operations and extension of maturities of FX swap operations in euro and US dollars to one month. These instruments have been backed also by the swap line with the Swiss National Bank and the repo facility with the ECB. As a result, a gradual improvement in funding conditions in the Polish inter-bank market occurred as bilateral quotations on the interbank repo market for longer-thanovernight maturities reappeared.

At the government's initiative, the Parliament also passed a law regulating the conditions and modalities of liquidity support for financial institutions and changed the law on the operations of the state-owned Bank Gospodarstwa Krajowego, which supports the government's social and economic programs, as well as local government and regional development projects. The laws allow for recapitalization of troubled financial institutions and provision of guarantees.

The liquidity provision by the NBP and the enacted laws were accompanied by the decisions of the Polish Financial Supervision Authority (KNF). As the Polish banking sector is dominated by foreign-owned banks, the KNF regularly meets parent banks' representatives to asses their economic situation and strategic plans regarding subordinated banks. Moreover, at the domestic level, the KNF closely monitors liquidity, foreign currency exposures and transactions with counterparties abroad, and issues recommendations on good practices for the banking sector. Recently, the KNF suggested to build a precautionary capital buffer targeting the solvency ratio at 10 percent. The KNF is also involved in the supervisory colleges for major domestic financial institutions.

Although the authorities consider to have taken appropriate measures and to be well prepared to withstand the international financial crisis, access under an FCL would help safeguard against downside risks. 